Portland State University

PDXScholar

1975

\title{
Britain's Colonial Administrations and Developments, 1861-1960: An Analysis of Britain's Colonial Administrations and Developments in Nigeria
}

Efiong Isaac Utuk

Portland State University

Follow this and additional works at: https://pdxscholar.library.pdx.edu/open_access_etds

Part of the Political History Commons

Let us know how access to this document benefits you.

\section{Recommended Citation}

Utuk, Efiong Isaac, "Britain's Colonial Administrations and Developments, 1861-1960: An Analysis of Britain's Colonial Administrations and Developments in Nigeria" (1975). Dissertations and Theses. Paper 2525.

https://doi.org/10.15760/etd.2521

This Thesis is brought to you for free and open access. It has been accepted for inclusion in Dissertations and Theses by an authorized administrator of PDXScholar. Please contact us if we can make this document more accessible: pdxscholar@pdx.edu. 


\begin{abstract}
AN ABSTRACT OF THE THESIS OF Efiong Isaac Utuk for the Master of Science in Teaching presented November 3, 1975.
\end{abstract}

Title: Britain's Colonial Administrations and Developments in Nigeria 1861-1960. APPROVED BY MEMBERS OF THE THESIS COMMITTEE:

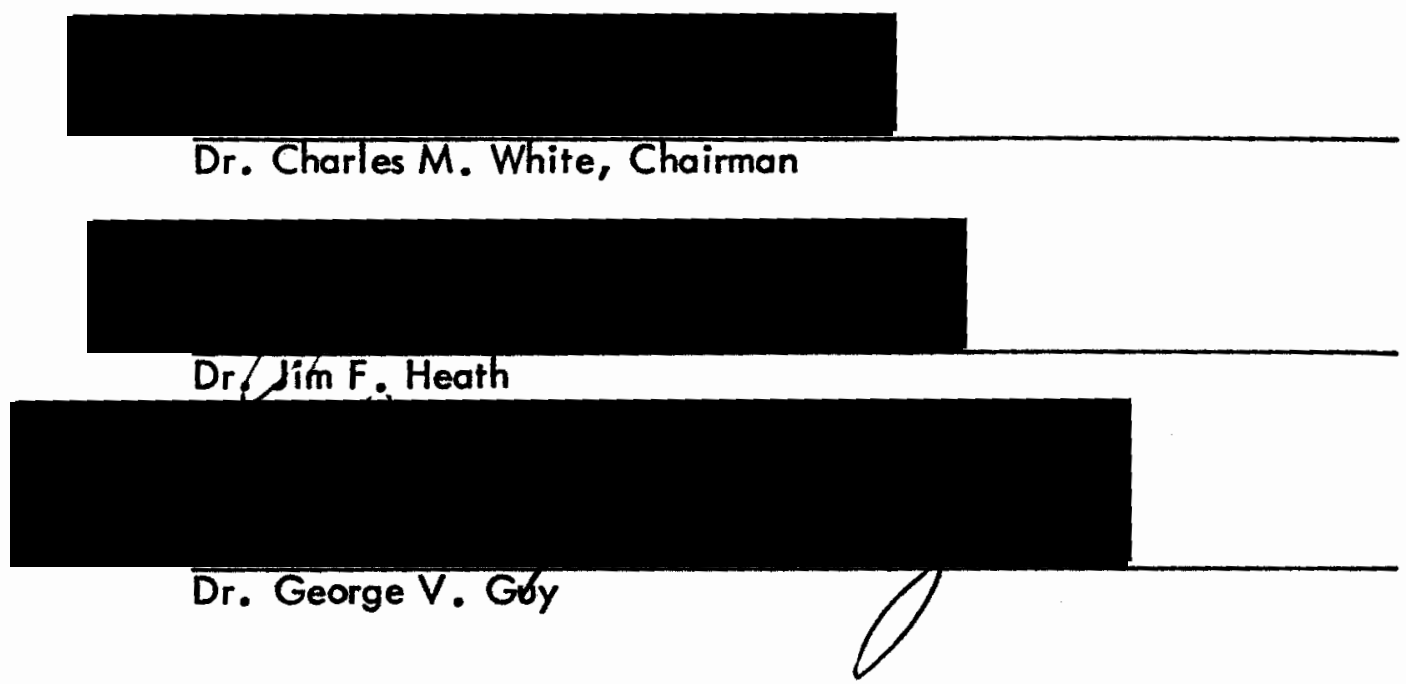

This thesis is to indicate the positive British role in developing Nigeria during the Colonial period to the point that effective self-government became possible. The study is approached analytically, utilizing information primarily from printed sources, but including conclusions from the author's experience and informal interviews from local chiefs who lived through much of the Colonial period.

Between 1849 and 1906, West African territories were occupied by several European powers who subjected the peoples to a new type of administration. In Nigeria, Britain was the Colonial master. The British unquestionably benefited 
economically from their control of Nigeria, but, to their credit, they also endeavored to create a colony in which the subject peoples would ultimately be able to take over the country's administration. Side by side with the British Government, commercial and religious groups with economic and religious motives, moved into Nigeria and introduced new concepts and practices of the western world. Barriers to effective administration and rapid advancement of native authority during the initial stages of British control were due, not to the shortcomings of the British Administrators, but, rather, in large measure to the traditions and social structures of the various peoples. Moreover, sufficient revenue was not available due to the underdeveloped economic resources and because local taxation was not introduced in the early days of the British administration. Assistance in the form of revenue came from the British Government and commercial groups.

By the end of the Second World War administrative progress was encouraging, and radical approaches to democratic self-government reached a high peak. The process of transition to full-scale democracy on the British model proceeded rapidly. The British Government assisted the establishment of popularly elected majorities. The executive councils were taken over by politicians drawn from and responsible to the majorities. The system of one man, one vote was initiated. In general, Britain was remarkably successful in training Nigerians to assume control of their country, and the British efforts cannot be erased from the history books or from the minds of many Nigerians. The result was a united, viable, and independent Nigeria. 
BRITAIN'S COLONIAL ADMINISTRATIONS AND DEVELOPMENTS 1861-1960: AN ANALYSIS OF BRITAIN'S COLONIAL ADMINISTRATIONS AND DEVELOPMENTS IN NIGERIA

by

EFIONG ISAAC UTUK

A thesis submitted in partial fulfillment of the requirements for the degree of

MASTER OF SCIENCE IN TEACHING

in

HISTORY

Portland State University

1975 


\section{TO THE OFFICE OF GRADUATE STUDIES AND RESEARCH:}

The members of the Committee approved the thesis of

Efiong Isaac Utuk presented November 3, 1975.

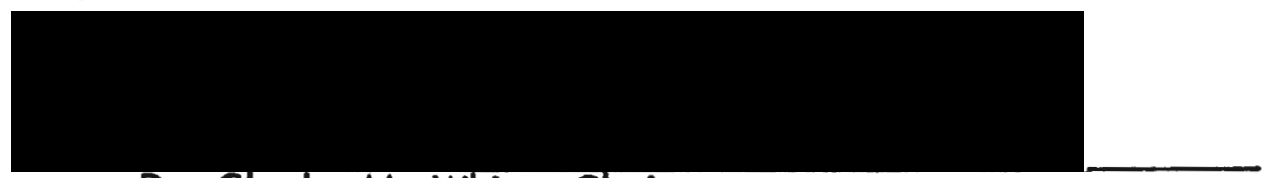

Dr. Charles M. White, Chairman

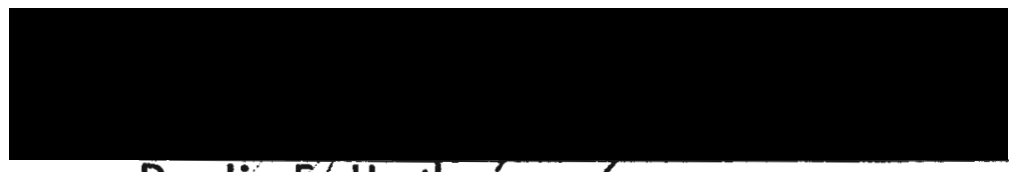

Dr. Jim F\% Hegth

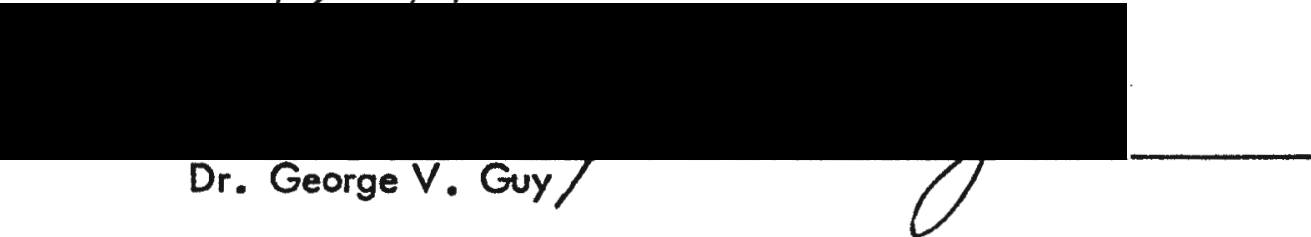

APPROVED:

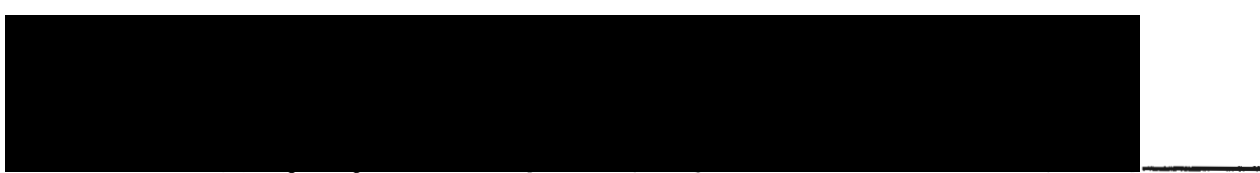

Dr. MichaelF. Reardon, Head, Department of History

'Richord B. Halley, Dean of Graduate Studies

November 3, 1975 


\section{ACKNOWLEDGEMENTS}

My cordial thanks are due to the staff in the History Department for their instructions, advice and guidance throughout my Graduate course. I am also grateful to the Financial Aid Department which gave me financial assistance during the last two years of my study. I am deeply grateful to Dr. Charles M. White, my chief adviser, for his sincere and tactful guidance during the preparation of this volume despite his other multifarious duties; to Dr. Jim F. Heath and Dr. George V. Guy, for their suggestions and encouragements; and to my wife, for dispatching some useful textbooks on the history of Nigeria, and for her patience. 
TABLE OF CONTENTS

PAGE

ACKNOWLEDGMENTS

LIST OF TABLES $\ldots \ldots \ldots \ldots \ldots \ldots \ldots \ldots \ldots \ldots \ldots \ldots \ldots$ vii

LIST OF FIGURES $\ldots \ldots \ldots \ldots \ldots \ldots \ldots \ldots \ldots \ldots \ldots \ldots$ viii

\section{CHAPTER}

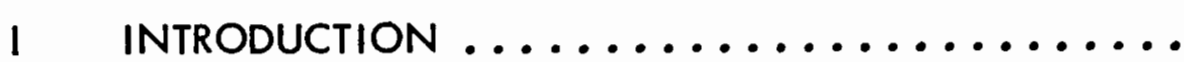

II ADMINISTRATION BEFORE THE COMING OF BRITAIN ....................

III ADMINISTRATION AND DEVELOPMENTS UP TO 1922

Planning of Administration . . . . . . . . . .

Organization of Administration ..........

Amalgamation -- 1914 .............

Conduct of the Government $\ldots \ldots \ldots \ldots \ldots \ldots$

Constitution of $1922 \quad \ldots \ldots \ldots \ldots \ldots \ldots \ldots$. .

IV POLITICAL DEVELOPMENT OF NIGERIA $\ldots \ldots \ldots \ldots .26$

Bernard Bourdillon's Plan ............ 26

Arthur Richards' Constitution ............ 28

Civil Service .................. 30

Regionalization $\ldots \ldots \ldots \ldots \ldots \ldots \ldots$ 
Chief Obamfemi Awolowo's Biography .........

Chief Awolowo's Views on Richards'

Constitution ....................

N.C.N.C. Criticism ................

Dr. Nnamdi Azikiwe's Short Biography ... . . . . . 38

Dr. Nnamdi Azikiwe's Federal Plans ........... 40

Chief Obamfemi Awolowo's Federal Plans ... . . . . 42

V FEDERATION OF NIGERIA ................ 43

John MacPherson's Constitution 1951-53 ........

Regional Boundaries

Regional Representation in the Central Legislature Revenue Allocation

Regional Autonomy

Ministerial Responsibility

A Brief Biography of Abubakar Tafawa

Balewa (1912-1966) ..................

The Lyttleton Constitution, 1954 ........... 57

Politics ............................ . . . 59

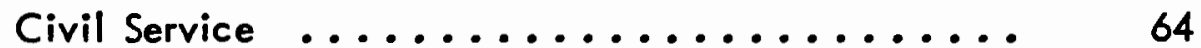

Foreign Policy ....................... 68

A Brief Biography of Sir Ahmadu Bello ... . . . . . 70

Public Finance ..................... 72

Defense and Internal Security ............. 76

Three Organs of Government ............. 80

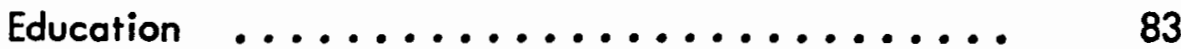


VI PRACTICAL EXPERIENCE IN SELFGOVERNMENT 1956-60 ................

Motion for Self-Government 86

Formation of National Government ......... 88

1954 Federal Government

89

Northern Region

Western Region

Eastern Region

Southern Cameroons

Ex Officio Members

Western Government ................

Eastern Government .................

Minority Fears .................... 


\section{LIST OF TABLES}

TABLE

PAGE

I Principal Ethnic Groups (Census 1952) 


\section{LIST OF FIGURES}

FIGURE

PAGE

I Nigeria -- Provinces $\ldots \ldots \ldots \ldots \ldots \ldots \ldots \ldots \ldots$

2 Administrative Organization 1920-1951 ...........

3 Nigeria - Regions $\ldots \ldots \ldots \ldots \ldots \ldots \ldots \ldots \ldots \ldots$

4 Nigeria Legislature 1951 ................

5 Federation of Nigeria .................

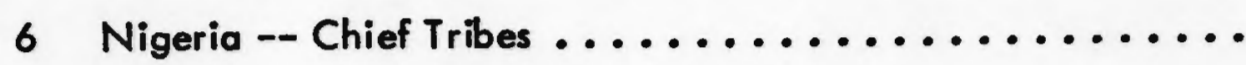




\section{CHAPTER I}

\section{INTRODUCTION}

On the first of October 1960, the British Union Jack was lowered and the green and white flag of Nigeria was hoisted in its place. Shortly after these two historical events the late Prime Minister, Sir Abubakar Tafawa Balewa, on behalf of all Nigerians, declared: "We are grateful to the British officers whom we have known, first as masters and then as leaders and finally as partners but always as friends." 1

According to a widely held view, Britain's Colonial rule in Nigeria did not make sufficient allowance for the growth in experience and influence of the Western-educated elites who were to play the chief part in creating the nationalist movement destined to take over the reins of government from Britain.

Nigeria was the home of the classic system of Indirect Rule which Sir

Fredrick (later Lord) Lugard, the father of that system, stamped upon a society widely different in kind, size and culture. The system was the only immediate means through which these different groups of peoples were saved from dictatorial systems of government. In addition, it was the channel for nationalization in bringing about the Western style of government. Nigeria did not achieve

'Bryan Sharwood Smith, But Always as a Friend -- Northern Nigeria and the Comeroons 1921-1957 (U.S.A., 1969), P. III. 
administrative unity until the North and the South were linked together in 1914. After the amalgamation, Britain, through the British administrators, initiated for elective assemblies. Through these assemblies different political parties sent their representatives and thus an administrative system on the Western model was created. The recruitment of Civil Service on the basis of merit, the separation of the public purse and business from the ruler and the assumption that all the people were entitled to equal treatment under the rule of law worked in different areas and established conditions essential for democracy.

The criteria on which my arguments are based are the individual and collective participation of the Nigerian political leaders under British leadership in constitutional developments which eventually led to a Parliament ary system of government and in other related developments in politics, civil service, public finance, defense, foreign policy and education plus the practical experience and influence of the political leaders during the period of internal self-government in which the leaders acted as premiers.

The period covered is 1861 to 1960 . The approach is analytical. The study is based on documentary evidence mainly from Nigerian textbooks on British administrations. Other information has been collected from Nigerian magazines. My personal knowledge as a Nigerion who had witnessed the Colonial rule for about a decade is used sparingly.

Nigeria is rich in oral history, and, although it is not documented, information has also been received from Chief Thompson Udo Nsuk, a traditional ruler, 
and Chief Jonah Udo Utuk, the first certificated teacher and a great historian in the Itam Clan. Both of these chiefs saw Colonial rule from its infancy.

The conclusion is strictly my own judgment, independent of other authors. Throughout the entire paper, the British roles are defended positively. It should not, however, be assumed that Britain did not play any negative role in the administrations and developments of Nigeria. The negative roles are obvious, but, they are outside the scope of this paper.

The word "Protectorate" is used several times in the text to mean a systematic declaration of the territorial status of the region included in the empire in which both external and, to a certain extent, internal sovereignty had been passed to the controling power. The sovereignty in many cases may be with the treaty consent of the people. 


\section{CHAPTER II}

\section{ADMINISTRATION BEFORE THE COMING OF BRITAIN}

Long before Britain took over the administration of the area which is now called Nigeria, ${ }^{1}$ certain types of governments were flourishing in the Northern Emir ates, ${ }^{2}$ and in the Eastern and Western Kingdoms.

In the North, the Hausas adopted a feudal system of government which was also inherited by the Fulanis, their conquerors. The important feature of the feudal system of government was that at first, the power was centralized and later on was delegated. The emirs were vassals of the Sultan of Sokoto, who was the chief of the emirs. However, Islamic laws did give specific powers to the emirs. Traditions and conventions also stated the boundaries of their power and thus made the feudal system of government workable.

Northern society was a complex one. ${ }^{3}$ It was heterogeneous in structure and composition, but varied in size, culture, race, language, and religion. For example, the emirate of Zaria in the Hausa days consisted of the Kajuru, Kauru, and Fatika groups, and when the Fulani came, the Kagarko, Lere, and Durum

\footnotetext{
${ }^{1}$ The name was given in 1899 by Joseph Chamberlain, the Colonial Secretary.

2 Political or administrative division, peculiar to Northern Nigeria.

${ }^{3}$ H. A. S. Johnson, The Fulani Empire of Sokoto (London, 1967), p. 166.
} 
tribes were added. By the end of the sixteenth century the Hausa had established a modern form of government in their states. In each of the states, there was a well-organized fiscal system and a trained judiciary. To the east of the Hausa states or emirates, the Kanuri had founded a dynasty in Bornu about a century before the modern states of the Hausa. Like the Hausa, the Kanuri had also established a relatively powerful type of government. In the rivers area of the North, both the Moslem and the non-Moslem peoples lived in small but autonomous units. Their government was built around the clan.

In about 1804 the Fulanis, a more orthodox Moslem sect arrived. Their leader, Othman Dan Fodio, with the hope to infuse greater vitality into the islamic faith of the Hausa, started religious warfare, the Jihad. 4

Historians have not agreed about the specific cause of this J ihad nor have they any conclusive evidence as to the motives of those who took part in it. Some held that it was a purely religious movement, and, even though the Fulanis provided the leadership, tribal distinction was of secondary significance. Others have maintained that religious manifestations were of superficial importance, that the real cause was ethnic. The general belief was that it was a revolution designed to give the Fulani control of the people among whom they settled. In fact, the Jihad represented a skillfully executed plot, masquerading under the guise of a movement for religious purification to install Fulani in place of Habe-monarchs. 5

${ }^{4}$ This is a general name for Fulani wars, against the Hausa infidels who rejected puritanical reforms.

${ }^{5}$ Habe-monarch means non-Hausa kings. 
By 1810 the Fulani rule became well-established over the Hausa States. In the West, culturally the most homogeneous area, the Yoruba and the Edo operated a modern form of government which was organized in cities and towns. In the rural areas the government was based on the clan. Oni of lle-lfe was the King. He ruled the territory through his own chiefs. The chiefs collected tribute from the people and divided it with Oni of Ife. In Ife, Ogboni, the local court, acted as the next higher tribunal where cases were referred. The final court of appeal comprised Oni himself, members of the Ogboni, and the town chiefs.

Outside Ife, Oba was the central chief. He was the priest as well as the protector of his subjects. He was the symbol of peace and honor but answerable to Oni of Ife.

In the Eastern territory, the most heterogeneous part of Nigeria, where the lbos constituted the majority of the population, there was a strong government. Except in the rivers area, the people were elaborately organized into small semiautonomous communities like the clan, the village, and the family. In the rivers area such as Calabar, Opobo, Bonny and Onitsha, Kingship was common. Kings in such areas like King Jaja of Opobo or Obi of Onitsho ${ }^{6}$ had political powers comparable to that of Oni of Ife. Government both at the clan or the village level was exercised through direct democracy. For example, in Itsekiriland, in the Niger delta, authority within the town rested on the founder and the elders

${ }^{6}$ Obi of Onitsha means King of Onitsha. Obi is still the official title of the King of Onitsha. 
who were consulted in all matters. Even so, they did not make decisions entirely on their own. In fact, a great deal of freedom was left to individuals. 7

In very remote lbo areas such as Arochuku, the most powerful legal instruments of authority were Oracles. The dominant Oracle was Chuku who was regarded by the Aros as the high gad and by some of the lbos as the only powerful being. The belief in Oracles provided spiritual, political, and economic needs. When the "Long juju" of Arochuku, the most powerful of these Oracles, spoke, those who were judged and found guilty were requested to pay for their guilt in the form of slaves to be sacrificed to the Oracle. In practice, however, they were sold secretly to slave dealers. Money thus obtained was shared between the agents and the owner of the Oracle. By this means the Aro people were believed to be protected by divine power. 8

In the lbibio area where this writer was born and raised, "Ekpo" was a strong political instrument through which discipline was maintained and authority preserved.

These different governments were organized under different situations, by different peoples, with different cultural backgrounds. These diverse forms of government exercised great influence on the making of Nigerian constitutional

7 Obaro lkime, Merchant Prince of the Niger Delta (London, 1968), p. 3. 8 John Hatch, Nigeria: A History (London, 1971), p. 68.

${ }^{9}$ Adult society, women excluded. 
forms, and are responsible for first, a unitary, second, a decentralized, and finally, a Federal Government. 
CHAPTER III

\section{ADMINISTRATION AND DEVELOPMENT UP TO 1922}

\section{PLANNING OF ADMINISTRATION}

Dosumu, the King of Lagos, and his chiefs declared Lagos a British possession on August 6, 1861, after a formal treaty had been signed with Consul John Beecroft, a British representative. In 1862, Lagos was created a Colony or "Settlement." For a few years, until 1868, administration of the Colony was left in the hands of Consul John Beecroft who was also in charge of the Bights of Benin and Biafra. ${ }^{2}$ His administration was ineffective and unsatisfactory because the administrators were few and scarce, particulorly ofter 1862 when the administrative area was extended. Consul John Beecroft made treaties with the chiefs of the Oil Rivers, ${ }^{3}$ the chiefs on both banks of the River Niger, as well as from the Fulani Sultans of Sokoto and Gando. ${ }^{4}$ These areas were placed under British protection; but there were not enough officers to oversee those oreas. The shortage

'Sir Allan Burns, History of Nigeria (London, 1969), p. 131. ${ }^{2}$ The whole area extending from west to east on the shores of the Gulf of Guinea.

3 The whole area extending from Benin River west of the Niger to the Cameroons territory in the east. The area includes Benin, Onitsha, and Calabar.

${ }^{4}$ Territories northeast of the Benue River. 
was aggravated by the practice of some of these administrators taking frequent leaves of absence on the grounds that the tropical climate of Nigeria was harmful to their health.

In order to establish a satisfactory and effective form of administration, systematic planning was necessary. The planning of administration for Lagos Colony and the protected areas was placed in the hands of a committee whose members had long experiences in Africa or Nigeria. George Goldie, who was one of the planners, was the head of the Royal Niger Company located at Lokoja, a town on the confluence of the Niger and Benue Rivers. Mary Kingsley, who advocated a traders' government, ${ }^{5}$ did an extensive study of West African countries and was also with the Royal Niger Company for a long time. Other members on the planning committee included Hector McCallum, the governor of Lagos who was later replaced by Sir W. Mac Gregor; Sir Clement Hill, who had been in the foreign office and had served in the African Department in London; Sir R. Antrobus, who was head of the West African Department of the Colonial Office; and Lord Selborne, who was the chairman of the planning committee; Ralph Moor, Commissioner of the Niger Coast protectorate; and a few senior clerks. There is no supportive evidence to indicate that Nigerians were included in the committee, but it is very likely that C. A. McCallum contacted some prominent chiefs for suggestions before he left for the meeting.

51. F. Nicolson, The Administration of Nigeria 1900-1960 (London, 1969), p. 27. Government controlled by officers of trading company. 
The first immediate matter discussed by the planning committee was to settle the question of organization of the country: whether the administration was to be united in the hand of one person or whether it should be left in the hands of many. If the latter were to be chosen, into how many administrations; what arrangements should be made for military forces; what form of taxation should be adopted and how much revenue could be expected. The next group of questions concerned the Northern provinces: what type of policy would be suitable for Sokoto and Bornu; would the Resident be stationed in Sokoto. The question of a railway for the North was also considered.

The Selborne Committee considered it unnecessary to establish a Resident Governor-General for the whole of the territories since the task of administering would be too much for one person. Rather, they decided to keep provincial governors who would be responsible to the Colonial Office. With this decision the proposal was made to divide the territories into a Maritime Province and a Sudan Province. 6 The Mohammedan Yorubas were included in the Maritime Province and Ilorin in the Sudan Province. The seats of the governments would be of Lokoja and Asaba. ${ }^{7}$ Each of the two provinces was to be divided into divisions and each division into districts. The subdivisions aimed toward easy and effective administration. However, the two major divisions were not followed; instead, three divisions were created: a colony of Lagos (including Yoruba protectorate)

\footnotetext{
${ }^{6}$ Nicolson, Administration of Nigeria, p. 30.

${ }^{7}$ Asaba is a town on the Niger delta.
} 
and a Southern and a Northern protectorate. Military forces were to be under one command. The planning committee estimated the total revenue to be four hundred thousand pounds a year and the total civilian expenditure at three hundred forty-eight thousand four hundred pounds, while that of military was estimated at three hundred fifty-one thousand pounds. Thus, there was to be a deficit of three hundred thousand pounds. It appeared that the balance would come from the British government and the interest groups, since the committee did not consider it wise or necessary to impose direct taxation during the initial stage. But, they proposed including the chiefs in the administration in order to suggest to them that taxation will be imposed in the future. 8

The planning committee left the second group of questions concerning policy to George Goldie, confessing that they were ignorant of what policies would be suitable. Goldie did not consider a Resident as a necessity for the North while the Fulani power was still recognized. The Fulani rulers at first ruled with justice, but later on as they became more and more powerful they oppressed their own people. ${ }^{9}$ A railway line was to run from Kano, a historical town in the North, to the Niger so as to give easy access to Lagos, Warri and Asaba in the Western territory.

On the tenth of April 1899, which was the end of the Selborne Planning Committee, Joseph Chamberlain named the country "Nigeria." The most

$$
\begin{aligned}
& { }^{8} \text { Nicolson, Administration of Nigeria, p. } 32 . \\
& { }^{9} \text { Burns, History of Nigeria, p. } 52 .
\end{aligned}
$$


important significant feature of the planning committee was the total concern about better and effective administrations and developments of the country. The committee was particularly and deeply concerned about a better means of communication, plans to include chiefs in the administration, financial assistance and manpower.

\section{ORGANIZATION OF ADMINISTRATION}

On January 1, 1900, Britain hoisted the Union Jack at Lokoja. From that date Nigeria was administered either directly or indirectly by the British Government in three separate units: first, the colony and protectorate of Lagos which consisted of areas of authority of the present Western States and Lagos State government. Second, the protectorate of Southern Nigeria which comprised roughly the areas of authority of the present three Eastern States and of the Midwestern State. Third, the protectorate of Northern Nigeria which was more or less the same as the present six Northern States. Lagos served as the headquarters. In 1906 the Colony and Protectorate of Lagos and Protectorate of Southern Nigeria were merged into one administrative unit known as the Colony and Protectorate of Southern Nigeria. The North was administered as a separate political unit. Each section was divided into provinces for administrative convenience. Provinces in the North were Sokoto, Kano, Katsina, Bornu, Bauchi, Zaria, Yola, Muri, Nupe, Kontagora, Ilorin, Nasarawa, and Munshi. Southern provinces comprised: Abeokuta, Benin, Ondo, Oyo, and Warri for the West and Calabar, Owerri, Onitsha and Ogoja for the East. Each of these provinces was under the control of a British Resident. Responsible to him were other administrative officers 
who in turn controlled the subdivisions of the provinces, the districts. In each of the districts, traditional rulers and head chiefs remained in charge of their area of authorities but were responsible to the district officers who in turn were responsible to the chief executive of Lagos Colony, the governor, through the Resident.

In 1913, Lord Frederick Lugard set up the Nigeria Council comprising thirty-one members: the governor, the members of the Executive Council, the Senior Resident and a number of unofficial members, both Europeans and Africans. Chief Dore Numa of Gwato ${ }^{10}$ was one of the two African members. The Council was formed to give an opportunity for the expression of public opinion and to discuss governor's speech. "It had no power over legislation, which rested completely with the governor. This Council was abolished in 1922 because the members did not take seriously their positions, on what they regarded as little more than a debating society. However, in its lifetime it did help to establish a closer relationship between the people through their chiefs and the government.

In 1914, a small legislative council for the colony was created. Of the four unofficial members nominated, two were Africans. Chief Numa was a member since he was the government's most trustworthy political agent in his area of authority. The council had the power to legislate for the colony only. Like the Nigerian Council, the small legislative council was abolished in 1922. The council did give some experience and influence to the Africans in legislation.

${ }^{10}$ Gwato is a town on the Benin Coast. 11 Margery Perham, Native Administration in Nigeria (London, 1962). 


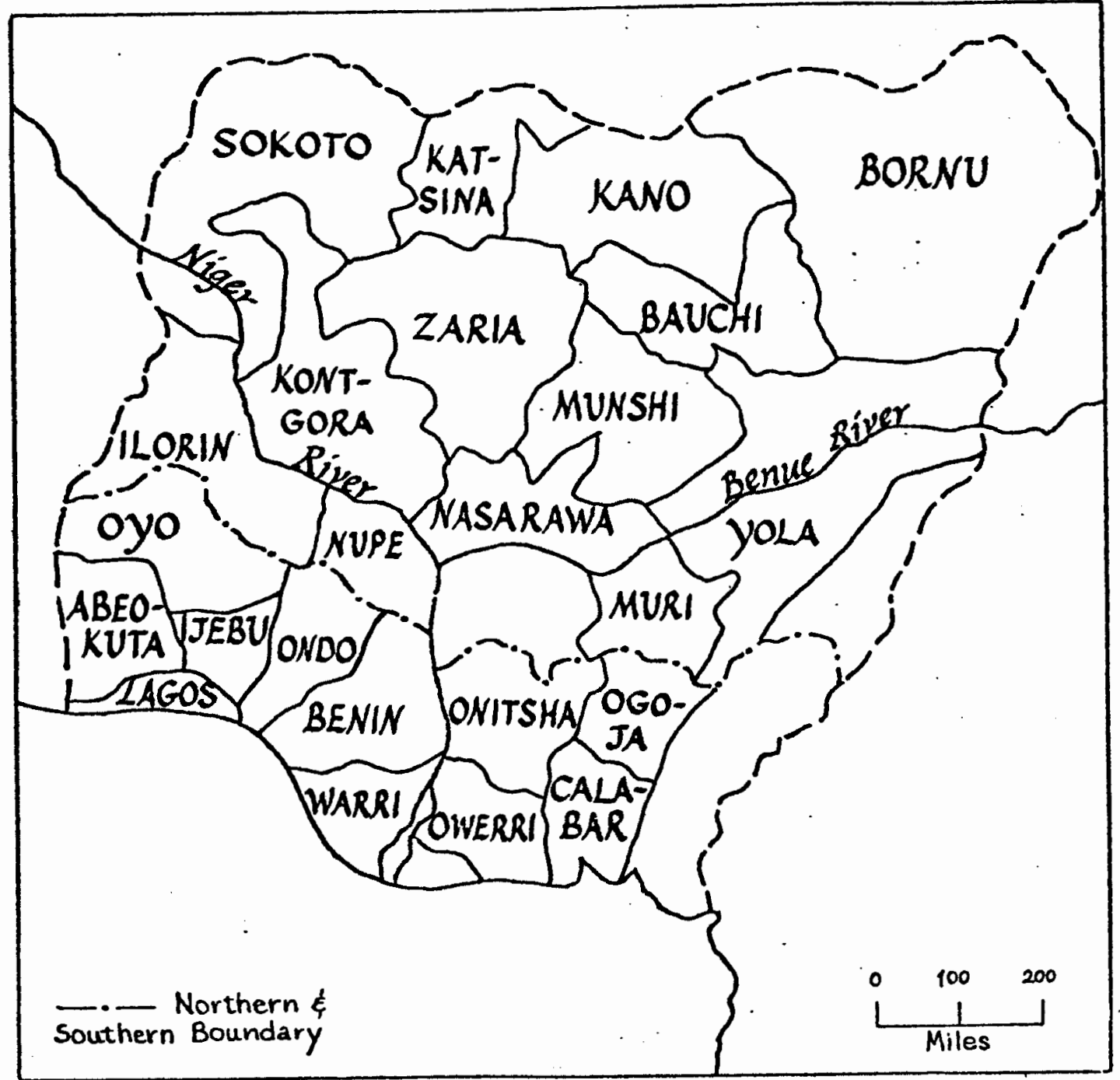

Figure 1. Nigeria -- Provinces. 
On the local level, Lugard organized, retained, and strengthened the Organization of Native Authority in the Sokoto and Bornu States. Emirs remained in charge and powers to administer certain functions, like settling of cases, were given to them. Policies formulated by the British officers were administered by the emirs. In effect, Lugard refrained from any action that would interfere with the exercise of the Mohammedan religion, custom, or tradition, because he believed that an effort to weaken these important cultural attributes would also weaken the power of the emirs to control.

A Native Authority system was not established in all parts of the North, since Lugard held that good government was not equivalent to self-government. He wanted the Northern section of non-Moslems living in Plateau, Benue and Adamawa provinces ${ }^{12}$ to have a separate administration. Hugh Clifford, Lugard's successor, ignored this plan and extended the administration to include the nonMoslem areas. Lugard's plan aimed at a more liberal opportunity for non-Moslems to advance socially within a short period of time, as they would not be subjected to Moslem laws and customs.

The Native Authority system was subsequently established in the West and in the East. It worked better in the West because the Yorubas had already been acquainted with organized system of government. In the East Lugard met with some difficulties. First, the chiefs did not possess strong political power like the

${ }^{12}$ After 1906 some names of provinces in the north were changed; addition made in the south: e.g., Bauchi to Plateau, Nasarawa to Kabba, Yola to Adamawa; ljaw province added to the east. 
Obas in the West or the Emirs in the North. Second, the easterners were used to a semi-democratic system of government. In Lagos, where there was a large European population, administration was direct. The traditional rulers had no political functions to perform.

\section{AMALGAMATION -- 1914}

By 1912, the administrations in the Northern and Southern protectorates had been well established. But there was a growing need for a better and more effective organized form of administration for the whole country. One of those who spoke in favor of bringing the North and the South together was E. O. Morel. He did not want the North and the South to continue as two separate territories because, by remaining separate, the development of the whole country would be retarded. For example: custom duties levied on trade with the North accrued to the South which owned the seaboard. The North, thus impoverished, had to rely on the British treasury for financial support. Unification of the North and the South would bring a better financial management to the country in the immediate and remote future. Morel pointed out that the coming together of the two areas would result in a better and more effective administration and a more sensible division of the entire country into provinces. He advocated that the united country be divided into four provinces to comprise Sokoto, Kano, Bornu and Zaria; central provinces to consist of the non-Moslem section of Zaria, Bauchi, Niger, Yola and Muri provinces; western provinces to include Oyo, Abeokuta, Ondo, 
Benin, Kabba, Ilorin, Warri and liebu provinces; eastern provinces to be made up of Calabar, Owerri, Onitsha, Ogoja and ljaw.

This plan called for a lieutenant governor to be in charge of each province and for Lagos to be administered by a Resident. The chief executive would be the Governor-General.

Sir Frederick Lugard was therefore invited to return to Nigeria in order to carry out the amalgamation. He made his own recommendations to the British government in 1913. In 1914 Southern and Northern Nigeria were amalgamated as one country and Frederick Lugard became the First Governor-General. ${ }^{13}$

The significant consequence of the amalgamation was the deliberate extension of the emirate philosophy of the NativeAdministration to the South. In the first place, the Northern Courts Ordinance which was created in 1914 was thus used in the whole of the newly-united country. In the second place, the Northern Ordinance of 1916 extended Native Administration to the South. The Northern Native Revenue Ordinance too, was applied in the West in 1916, and introduced in the East in 1928.

For the purpose of administration, the division of the country into North and South was retained in order to ease the complication of the duties of lieutenant governors. This new arrangement meant thot most of the functions which previously were not given to the Governor-General were transferred to the Governor-General both in the North and in the South. Under this arrangement,

13 The fitle was personal to Sir Lugard because his successors went with the title of Governor. 


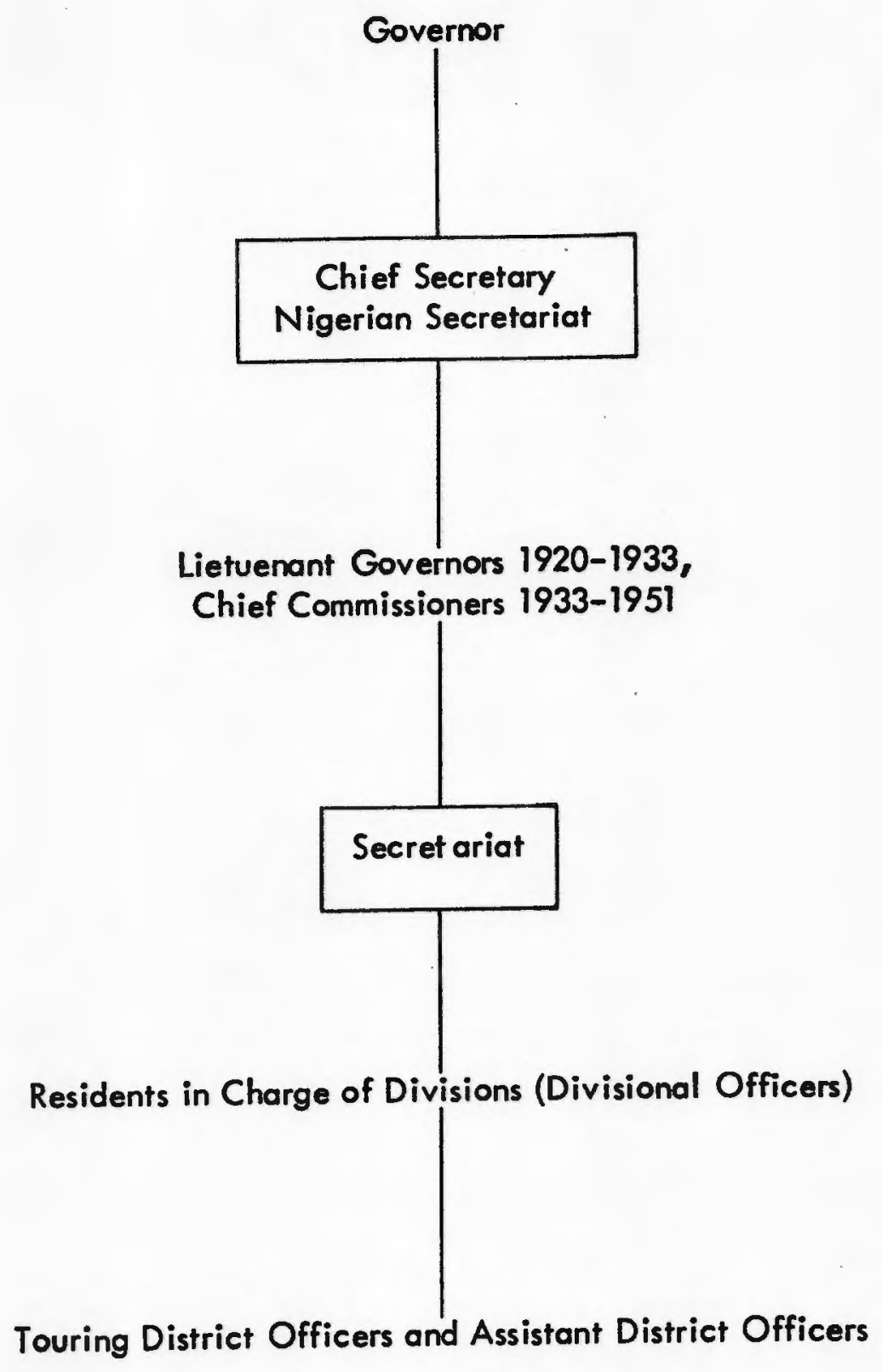

Figure 2. Administrative Organization 1920-1951. 
the Governor-General controlled the whole government with executive council advising him. One lieutenant governor was kept in charge of the North and the South. The lieutenant governor who assisted the Governor-General was in turn assisted by the Residents. The Residents were assisted by the district officers who in turn were helped by the native district heads in performing all the dignified Native Ceremonies. In this way, the emirs and the native district heads were given true training for self-government and new responsibilities. ${ }^{14}$

\section{CONDUCT OF THE GOVERNMENT}

The government which was to rule Nigeria for a quarter of a century required a good deal of ingenvity and unremitting labor and skill. The executive and legislative bodies functioned as in the parliamentary government. The members of the executive branch were nominated by the governor. The legislative branch comprised officials and non-official members but, nominated by the governor. Nominated Africans were the minority. The executive council had advisory powers while the power of the legislative body was limited to the Colony only. The legislative council was a mere debating body which could not effect any outstanding change aimed toward adequate representation.

The administrative branch was divided into two sections: one was departmental and the other was political. The departmental section was mainly concerned with supervision of Native Authority, directing of policy, education,

\footnotetext{
${ }^{14}$ S. J. Hogben and Kirk Grene, Emirates of Northern Nigeria (London, 1966), p. 133.
} 
legislation, levying of taxes and administration of justice. The departmental subdivision was in charge of technical functions such as communications, transportation and other material developments of the country.

The political officers were directly responsible to the governor. They supervised both technical and political matters. The lieutenant governors and the Residents were able to devote more time to the work of the Native Administrations.

The Court System was arranged in ranking order. The Supreme Court came first in the rank, but was considered unsuitable as a form of tribunal at the early stages of African civilization. The power of the Supreme Court was limited to criminal cases, and its jurisdiction did not extend to all areas in the South because a provincial court system was adopted. The Provincial Courts did not admit legal practitioners since the legal practitioners could not be effectively supervised by the professional judges. Procedures in the Provincial Courts were similar to that of the Supreme Court except that all types of cases could be heard summarily and barristers were not allowed to participate. 15

At the bottom of the ladder was the Native Court system. District officers were members. Participation of the district officers was advantageous in the sense that impartial judgment was always given. Their presence also limited the bad practices of some of the Court Clerks who encouraged bribery by receiving money from the people who sought their help.

${ }^{15}$ Nicolson, Administration of Nigeria, p. 202. 
An appeal could be made to the Supreme Court from the Provincial Courts. The Supreme Court consisted of a Chief Justice and two or more judges. Cases in the Provincial Courts were reviewed by the Resident.

\section{CONSTITUTION OF 1922}

In 1919, Sir Hugh Clifford replaced Lord Lugard as the governor of $\mathrm{Ni}-$ geria. There had long been a growing agitation by some of the Nigerians living in Logos for changes in administration because African representation in the executive branch was nil and in other branches not adequate. Moreover, there was need for reorganization of the administrative machinery and reconstitution of the legislature. The Nigerian Council started by Frederick Lugard was considered inadequate as just a debating society. The Legislative Council established for the Colony with its extremely limited powers was also unpopular. A new constitution was therefore, in 1922, introduced by Governor Hugh Clifford.

The Nigerian Council and the Legislative Council for Lagos were abolished. By the Nigerian Order-in Council, in the same year, a Legislative Council for Nigeria was established. The Council had the power to make laws for the Colony of Lagos as well as for the Western and the Eastern provinces of Nigeria. For the Colony and Southern protectorate, the Council retained its powers on all matters but only on financial matters for the Northern territory. For other matters affecting the Northern territory, the Governor legislated. There were thirty-one 
official and twenty-one unofficial members in the Council. Of the unofficial members, ten were Nigerians. 16

From 1923 to 1946 the Nigerian-nominated membership into the Legislative Council was as follows: the Colony and Abeoleuta, Oyo, Warri and Rivers provinces were each represented by one nominated member. All lbos were represented by one person. Ilebu and Ondo provinces, the Ibibio and Calabar province and the Cameroons were represented by one person each from 1938 to 1946. Representation of the Niger African traders was started in 1923 but was discontinued in 1943. The provinces of the Western region were thus better represented than those of the Eastern provinces. The Northern provinces were left out completely. The criterion for determining representation was not known. It is, however, quite clear that population was not taken into consideration; otherwise, lbos, for example, would have more representatives. It might be that geographical rather than population factor was used. Nevertheless, it was a liberal constitution. 17 It made it possible for franchise to be given for the first time to the people of Lagos and Calabar. The right to vote was given only to adult males who were British subjects or native to the protectorate and who possessed a residence qualification of twelve months and a gross annual income of one hundred pounds. 18

\footnotetext{
${ }^{16}$ Obomfemi Awolowo, The People's Republic (London, 1968), p. 27. ${ }^{17}$ Michael Crowder, A Short History of Nigeria (U.S.A., 1966), p. 256. 18 The amount was reduced to fifty pounds in 1946.
} 
If all the above qualifications were strictly followed, those who voted were very few, for the great majority of the people, including the working class, hardly reached one hundred pounds gross annual income.

Herbert Macaulay, the grandson of Bishop Crowder, founded the Nigerian National Democratic Party, following the introduction of the 1922 constitution. His purpose was first, to send representatives into the Lagos Legislative Council; second, to establish branches of the party throughout Nigeria; and third, to Africanize the Civil Service. Prominent members in the party were J. E. Egerton, Eric O. Moore, John Payne Jackson, Thomas Horatius Jackson, and J. T. White.

The Nigerian National Democratic Party with Macaulay as the leader, won three seats in the Lagos government in 1923, 1928 and 1937 elections. Edward Blyden, John Jackson and Dr. C. C. Adeniyi-Jones were the elected members. Jackson and Blyden lived for twenty-eight years in Lagos and Dr. Jones was the first medical practitioner.

Macaulay did not win any election into the Lagos government for forty years. But, he and the elected members gained much knowledge and wide experiences in the Lagos government. Macaulay also had sufficient influence in the country's affairs that he was given the title, "Father of Nationalism, "19 by the party members. As a nationalist, he spoke vehemently against Lagos government over the levy of Lagos water rate. His point against was that the levy was

${ }^{19}$ Crowder, Short History, p. 254. 
to benefit only Europeans of the Lagos area. He and his members in the party were fighting against the government to create more opportunity for more Nigerions to take part in the government. He was also the leading advocate of the famous Appapa case between the Lagos government and the Lagos citizens. He stood firm with the natives against the government in the Eleko ${ }^{20}$ versus the government in 1928. In effect, Macaulay and his party members exhibited self-determination. By the end of the second World War, self-determination was the only fundamental principle which guided Nigerian elites to request a more liberal constitution.

${ }^{20}$ El eko means hereditary ruler. Government wanted to withdraw recognition of these rulers. 
CHAPTER IV

\section{POLITICAL DEVELOPMENT OF NIGERIA}

\section{BENARD BOURDILLON'S PLAN}

Two historical events gave rise to Nigeria constitutional developments: first, by 1948 India, which had been under the British rule, achieved independence with the guidance of the British Government. Second, the Gold Coast (now called Ghana), a British West African Colony, under Dr. Kwame Nkrumah's leadership, had much progress in parl iamentary system of government. In Nigeria, therefore, it seemed appropriate to institute a parliamentary system of administration on the British model. To achieve this, some interested Nigerians, through the Colonial government, sought admissions into some British universities in order to study the British system of administrations. The public service which was staffed and manned mostly by foreigners had by this time started to take in $\mathrm{Ni}$ gerians. These Nigerians were guided and instructed on the intricacies of the English local government and administration.' Some non-Nigerians doubted whether parliamentary system of administration was, in fact, suitable in Nigeria. Their doubts centered on the fact that there were great diversities in language, religion, custom and outlook in Nigeria. But none of the critics provided any

\footnotetext{
1966), p. 20.

'John P. Mackintosh, Nigerian Government and Politics (Great Britain,
} 
alternative. However, there were others who argued that parliamentary system of administration could not be avoided. The latter feeling came as a sign of goodwill in Britain's mind for the development of a new Nigeria. The plan to be provided was, by and large, to allow the educated Nigerians to see themselves primarily as Nigerians who would be charged with the responsibilities of controlling the Nigerian Government.

In 1939, Benard Bourdillon divided the South into Eastern and Western provinces. ${ }^{2}$ This division was a deliberate action. He wanted a better and effective administration. During this time, the Northern provinces sent no representatives to the Lagos Legislative Council. Later two to three senior British officials from the North did attend the Legislative Council, but even then, they did not represent the interest of the Northern people. Rather, they represented the interest of the British citizens doing business in Nigeria, such as the British mining and the commercial groups. All legislative matters pertaining to the North, with the exception of money matters, were enacted by the Governor. The exclusion of the Northern provinces probably was due to distance and inadequate communication. But differences in religion and customs may also have been factors. 3 In a sense, it meant that the North did not share directly in advising the Governor except through the Chief Commissioner. Bourdilion thought it wise to bring in the North to share in the Legislative Council and to take port in advising the

$$
\begin{aligned}
& \text { 2Eme O. Awa, Federal Government in Nigeria (U.S.A., 1964), p. } 16 . \\
& 3 \text { Sir Bryan Sharwood Smith, Recollections of British Administration in the }
\end{aligned}
$$
Cameroons and Northern Nigeria 1921-1957 (U.S.A., 1969), p. 119. 
Governor in matters affecting them. His first plan was to establish regional councils to serve as provincial legislature and a Federal Council in Lagos. The provincial legislature was to serve as advisory body. Alternatively, he was to establish three parallel first Chambers with Lagos Council serving as a second Chamber. Bourdillon did not want the regional councils to have power other than legislative. They might also act in the advisory capacity but could not pass bills into law. Enactment of bills into law rested with the Lagos Council. The Central Council at Lagos was to consist of regional council members and a few officials and non-officials directly representing the country. Bourdillon did not put his plans into practice before he retired.

\section{ARTHUR RICHARDS' CONSTITUTION}

In 1945, Sir Arthur Richards succeeded Bourdillon. His main task was to create a type of government in which the different elements could advance steadily toward a more closely integrated units. His first move was the combination of the Native Authorities and the regional councils together. These bodies were brought together through representatives into one legislative body in Lagos. Three regional councils, one for the North, one for the East, and one for the West were created. But these councils had no legislative power nor were they able to deal with matters in connection with taxation without reference to the legislative body in Lagos. They had the power to discuss any bill and financial legislative measures, but could not enact these bills into law. The enactment of bills into law rested with the Lagos legislature. In this manner, the Richards 


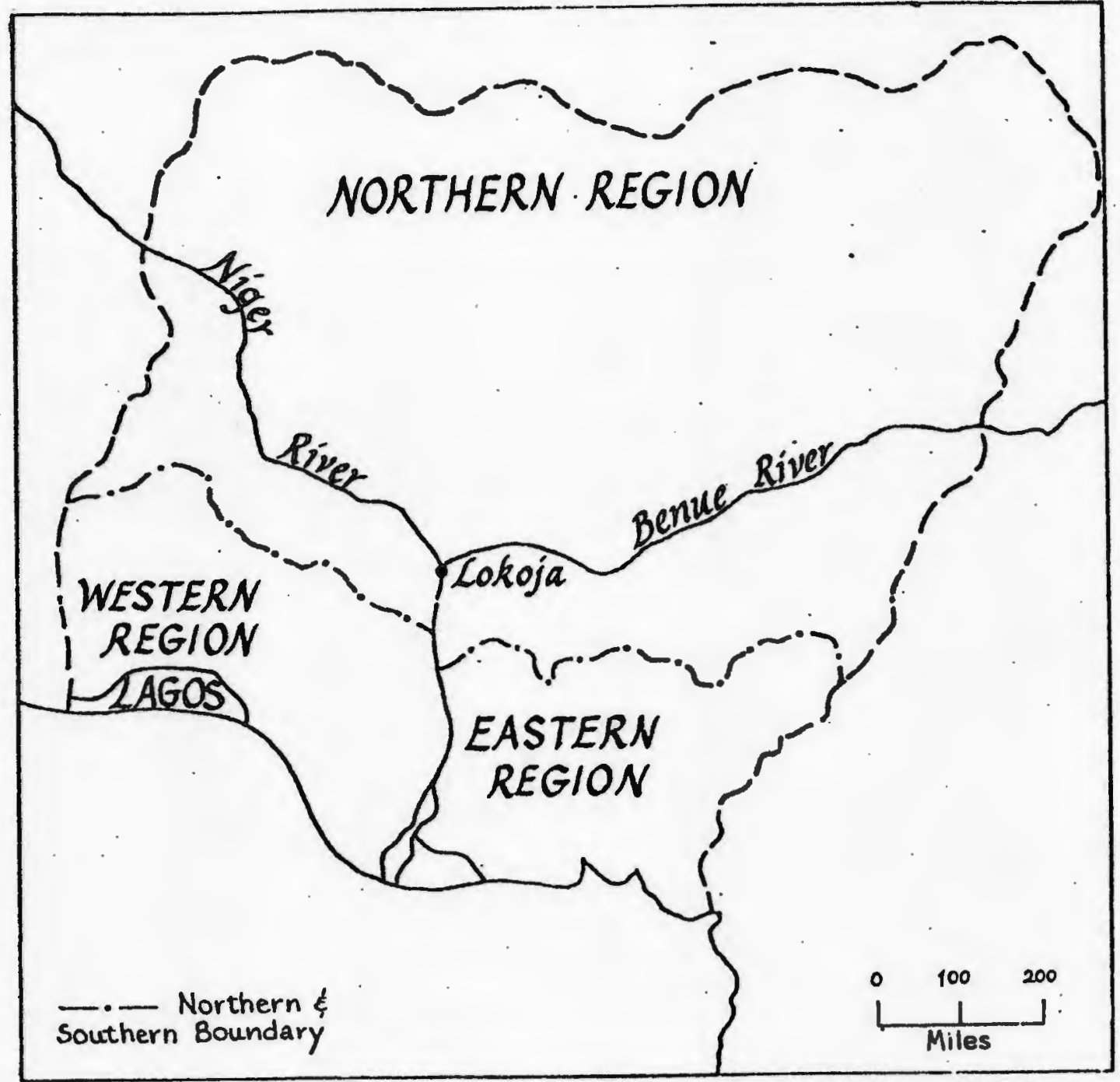

Figure 3. Nigeria -- Regions. 
Constitution ${ }^{4}$ was unitary since it placed emphasis on the unity of the country. It also provided an opportunity for each region to be aware of and deal with their problems. Besides, the emirs and chiefs were included within unofficial majorities. 5 The Constitution was also useful in that it set up a Central Legislative Council for Nigeria and by orders in Council established three regional councils. Beyond this, it was considered a failure by many Nigerians, partly because its details were bitterly criticized and opposed and largely because it did not actually lead to self-government which was what Nigerians needed most.

In the author's opinion, even though Nigerians were excluded in the executive branch of the government where the real power lay, the unitary characteristic of the Constitution was good. The unitary system provided opportunity for appointments to public service merely by merit. Perhaps, if it were adopted beyond 1951, tribal and sectional interest would have been replaced by national interest. National interest is the key to a stable government.

\section{CIVIL SERVICE}

Nigeria Civil Service, as an element of the unitary government, came with the Richards Constitution. Since Nigerian Civil Service is discussed in Chapter V, only a few significant facts are stated here: first, the structure and

${ }^{4}$ The Constitution was named after the Chairman, Sir Arthur Richard, the then Governor of Nigeria.

${ }^{5}$ Frederick Schwarz, Nigeria -- The Tribes, the Nation or Race -- The Politics of Independence (London, 1965), P. 63. 
the organization of the Nigerian Civil Service was similar to that of the British Civil Service. ${ }^{6}$ Second, the Colonial government provided a large sum of money as scholarship funds for the training of Nigerians for responsible posts at lbaudan University and in the United Kingdom and in the United States of America. Third, although this administrative policy probably came from Nigerian leaders, the implementation was carried out by the Colonial government. Today, the Nigerian Civil Service is one of the best organized and controlled branches of the government in Nigeria.

\section{REGIONALIZATION}

Sir Arthur Richards had al ready created three administrative regions in $\mathrm{Ni}-$ geria. In the North, there were two-chamber legislatures. The East and the West had a unicameral council each. The Northern upper chamber was the House of Chiefs with thirteen first-class chiefs and ten second-class chiefs, all drown from the Northern provinces. The lower house was the House of Assembly. It consisted of the Senior Resident, eighteen officials, twenty-four non-officials, and eighteen elected Native Authority members. There were also six non-Moslem members nominated by the Governor to represent the interest of their communities. The Chief Commissioner acted as the president in the upper chamber, while the Senior Resident acted as the president in the lower house.

\footnotetext{
${ }^{6}$ Adebayo Adedeji, Nigerian Administration and Its Political Setting (London, 1968), P. 6.
} 
In the Western region, the House of Assembly had thirteen officials and fifteen non-officials which included three chiefs, nominated by the Governor. In the Eastern House of Assembly, there were thirteen provincial members, all drawn from the Native Authority members. The Governor nominated five prominent citizens to represent interest groups. In the West and in the East, the Chief Commissioner presided over the House of Assembly. The regional legislatures debated and initiated bills, except money bills. The Central Legislature had the power to enact all bills. But bills in the Central Legislature could be debated in the Regional House of Assemblies.

The inclusion of some Native Authority members of each region in the legislature for firsthand observation, and their participations in debating bills and other related matters was a good training of the natives in legislative procedures.

The revenue of the central government went to the regional governments in the form of grants. The regional revenue came from direct taxation. The Northern upper chamber had the power to veto or amend items in the regional estimate. The Houses of Assemblies in the three regions were authorized to make suggestions on budgetary items. The non-official members had the power to debate or reduce the items. The Central Legislature had the power to enact laws.

In the author's opinion, the Richards Constitution was an attempt to unite the three regions together. Representation to the Central Legislature by the regions was possible. In addition, a closer relationship between the central, the regional and the Native Authority was also possible. 
But, some Nigerian elites believed that the position of the local governments in relationship with the central and the regional governments was not clarified. It was not clear to them whether the local governments were autonomous units with powers, or whether they were merely local government bodies without power.

The people particularly needed a specific constitutional provision which would indicate that the Native Authorities were a part of the government which ought to be clothed with power. In their opinion, the Constitution failed to make this provision. They also believed that the Constitution provided the people with a bewildering hierarchy of administrative areas and political authorities: the central and the regional governments, the Native Administration, followed by provinces, divisions and districts. In their judgment, each of the three regions was very large territory with thick population. They needed sufficient representation in the regional House of Assemblies and in the House of Representatives. One of the few ardent critics of the Richards Constitution was Chief Obamfemi Awolowo.

\section{CHIEF OBAMFEMI AWOLOWO'S BIOGRAPHY}

Chief Awolowo was born on March 6, 1909 at Ikene, a little agricultural and peaceful town in Yorubaland. Throughout his boyhood, his ambition was to be a lawyer, a politician, and a journalist. He went to school at the age of five. His first school was a Wesleyan school at his home town. In 1924, he studied at 
the Baptist Boys' High School and taught as a pupil teacher ${ }^{7}$ after two years. He attended a Wesleyan college in 1927 and after a year qualified as a Provincial teacher. 8 At the Wesleyan school at Ogbe, Abeokuta, he started to lay his political foundation. 9 His companions were all radicals, who were interested in reading the Lagos Daily News, which was inspiring and nationalistic in outlook. In 1934, he took up appointment with the Nigerian Daily Times as a reporter in training. Between 1944 and 1946, he studied in the United Kingdom where he passed the Bachelor of Commerce London Examination with second class honors. He was called to the bar as a member of the Honorable Society of the Inner Temple after one year. He was a Minister of the Western local government and the Leader of the Government Business in 1953. From 1954-1959, he was the Premier of the Western region. Moved to the position as the Leader of Opposition in the Federal House of Representatives in 1960. His former position was occupied by his deputy, Chief Samuel Akintola.

${ }^{7}$ A pupil teacher means a probationary teacher whose initial salary was twelve shillings a month.

${ }^{8}$ A qualified certificated teacher whose appointment was permanent. His salary was raised to two pounds a month.

${ }^{9}$ Obamfemi Awo, The Autobiography of Chief Obamfemi Awolowo (London, 1960), p. 69. 


\section{CHIEF AWOLOWO'S VIEWS ON RICHARDS CONSTITUTION}

Awolowo welcomed the Constitution in principle, but criticized some of the details. ${ }^{10}$ Elsewhere, he preferred the constitutional plans to be given a test. "He believed that the Constitution was characterized with the same features which made the 1922 Constitution rejectionable. In his judgment, the position of the chiefs was still not settled or clarified. The chiefs were made legislators in addition to being the focuses of power in their respective communities. They enjoyed official confidence and were consulted by the government on vital issues of the government. He considered the system used in determining the size of the Regional Councils as improper. In the Northern region, the ratio was roughly 1 to 700,000 people; 1 to about 500,000 in the Eastern region; and in the West, it was approximately 1 to 300,000 people. He did not see why people should be nominated instead of electing them. What Chief Awolowo meant was that probably, unsuitable people were nominated. What troubled him most was that the Constitution deliberately developed the country into a Unitary State. He had this to say:

Since the amalgamation all the efforts of the British Government have been devoted to developing the country into a Unitary State. This is potently impossible; and it is astonishing that a Nation with wide political experience like Great Britain fell into such a palpable error. 12

$$
\begin{aligned}
& { }^{10} \text { Awo, Autobiography, p. } 173 . \\
& { }^{11} \text { Schwarz, Nigeria, p. } 63 . \\
& { }^{12} \text { Awo, Autobiography, p. } 173 .
\end{aligned}
$$


Awolowo did not condemn the territorial structure of the Constitution. His suggestion was that a Legislative Council of Nigeria should consist of twenty official members including eight members from each of the regional House of Assemblies. One member should represent Calabar, four members to represent Lagos and the Colony, and three nominated members. The Governor should preside over the Legislative Council. He accepted the reserved powers and the power to use an original and casting vote which was conferred on the Governor. He sanctioned the structure of the executive council, but added that the African members were to be selected from the non-official members of the legislative body.

For the regional Council, Chief Awolowo suggested that one House of Chief be created for the North and one for the West but none for the East. His final suggestion was that all the three regions should be autonomous and should deal with all the regional matters without any reference to the Central Legislature. What this meant was that each region, however small, was entitled to the same treatment as any other region, however large.

Chief Awolowo's criticism and suggestions are very strong indications that he had a deep knowledge of and a wide experience in the different forms of governments. His knowledge and experiences were due partly to his Western education but mainly to the influence of the British Colonial rule in Nigeria. 


\section{N.C.N.C. CRITICISM}

Collective criticism came from the National Council of Nigeria and the Cameroons. ${ }^{13}$ The criticisms of this party centered around representation. The members of the party believed that there had never been true unofficial majority in the Central Legislature. The members in this Council had not been able to make any outstanding improvement for the country.

The members of the party proposed setting up a quasi-federal constitution which would retain the three divisions as had been outlined in the Richards Constitution. In the opinion of the members, the Legislative Council would consist of forty non-official members. Five members were to come from Logos municipality, two from Lagos Colony, and eleven from each of the three regions. The Council would have the power to pass laws for Lagos on all matters, but its powers on the three regions should be limited to defense, foreign affairs, and currency matters. The Northern House of Chiefs was to be retained. But this house would exercise advisory functions only. The Chiefs in theory were to be substituted for the officials, since they were heads of the Native Administration and therefore, an integral part of the government. In the party's view, elections to the regional and Central Councils were to be based on adult suffrage.

${ }^{13} \mathrm{Dr}$. Nnamdi Azikiwe was the most outstanding figure, the leader of the party. 
In 1950, the Richards Constitution was revised. The revision called for the adoption of a quasi-federal form of government. Dr. Nnamdi Azikiwe was one of those who commented on the federalism.

\section{DR. NNAMDI AZIKIWE'S SHORT BIOGRAPHY}

Dr. Nnamdi Azikiwe was born on November 16, 1904 at Zungeru, in Northern Nigeria, where his father worked as a clerk in the Nigeria Regiment. But he was raised in Onitsha lbo. Onitsha is therefore his home town. He went to the Roman Catholic mission school and later to the Anglican mission school, all in Onitsha. He learned to speak the Yoruba language when he was at the Wesleyan Boys' High School in Lagos. He studied at the Hope Waddle Training Institute, at Calabar, in Ibibio land. While he was at the Lagos school, he gained efficiency in the use of the Yoruba language. During his school days, he claimed to have been inspired by the "Black Zionism" of Marcus Garvey, the teaching of the Reverend J. E. K. Aggrey, an American-trained minister.

After his early training, he worked as a junior clerk in Lagos but was not satisfied with the experiences he had as a junior clerk. He planned to go to America for further studies with the hope that one day he would establish a university in Africa. ${ }^{14}$ At the age of twenty-one, he left for America, where he studied at Howard University in Washington, D.C. He studied also at Lincoln University in Pennsylvania, where he received his M.A. degree in Political 14 The University of Nigeria, Nsukka, was built through his initiatives. 
Science. He also received his M.S. in Anthropology. While on a visit to London, he met a white African student whose feelings for Africans coincided with his own. Both of them came to a general conclusion that Africans should be more self-reliant instead of depending upon the Colonial government to provide them with employment. 15

In 1934, he was the editor of The African Morning Post in Accra, in the Gold Coast. On his return to Nigeria, he established the West African Pilot, the Eastern Outlook and the Cameroons Star. Three main elements were responsible in shaping and guiding his political activities in Nigeria. The first was the gradual growth of a militant press, the emergence of a "Negro Renaissance," which placed much emphasis on the discovery of Africa, and the "Black Nationalism" in the United States. The second element which fired his ambition while in the United States was the "sensationalism and pugnacity of American yellow journalism" and, particularly, the "obsessive race-consciousness" of American Negro newspapers. The third was his determination to place his newspapers in a position which will make them commercially successful. He was never tired of speaking about the unity of Nigeria: "We can never split -- no, never. We are not a party, we are a national government whose mission is the regeneration of our Fatherland." 16

${ }^{15}$ Nnamdi Azikiwe, My Odyssey: An Autobiography of Zik (New York, 1970), p. 208.

16 James S. Coleman, Nigeria-- Background to Nationalism (U.S.A., 1960), p. 224. 
In 1944, he established a small bank and in 1948, he was able to establish a larger one known as "The African Continental Bank." 17 He became the Premier of the Eastern Region in 1954. In 1959, he gave up the position of Premiership to Michael 1. Okpara and ran for Prime Ministership. He was the first African Governor-General of Nigeria in 1960, and held the office up to 1966.

\section{DR. NNAMDI AZIKIWE'S FEDERAL PLANS}

Dr. Nnamdi Azikiwe did not think it wise to divide Nigeria along ethnic lines as was done by Chief Awolowo. Chief Awolowo divided Nigeria into ten cultural sections. In Azikiwe's opinion, geographical rather than cultural lines should be followed. With this philosophy in mind, he arbitrarily divided Nigeria into eight units. These units were to be called protectorates, but comprising: (1) the Northern, consisting of Katsina, Kano and Zaria provinces; (2) the Northwestern, comprising Sokoto, Niger and llorin provinces; (3) the Northeastern was made up of Bornu, Bauchi and Adamawa provinces; (4) the Central, consisting of Kabba, Benue and Plateau provinces; (5) the Southern, including Warri, Benin, Onitsha and Owerri provinces; (6) the Southwestern, containing Ondo, liebu, Abeokuta and Oyo provinces and the Colony of Lagos; (7) the Southeastern, comprising Calabar and Ogoja provinces; (8) the Cameroons, embracing the Northern and Southern parts of the Cameroons.

${ }^{17}$ The Bank of British West Africa (B.B.W.A., now Bank of West Africa, B.W.A.) was the first banking influence in Nigeria. It was founded in 1891. 
According to his plan, the chief executive of the Federal government was to be the Governor-General. A Cabinet would be appointed to be the major policy-making organ of the government. Each of the provinces should elect four representatives to make up members of Parliament. The Legislative Council would be mainly concerned with the making of laws affecting the protectorates. The Legislative Council would constitute representatives on the basis of one representative per 50,000 people. By this suggestion, Dr. Nnamdi Azikiwe wanted Nigeria to have a Parliament and a Legislative Council to be given the responsibility of making laws affecting every region of Nigeria. He portioned out a wide variety of functions to the Federal government which included the following: to levy and collect taxes, duties imposts and excises; to borrow money; to provide general services; to regulate internal and external trade; to enact laws concerning nationality and the rights of aliens; to enact a law of bankruptcy; to establish the monetary system and a system of weights and measures; to enact laws in respect to land, water, forests, mines, police, insurance, education, industrial and agricultural establishment; transportation and communication; public health and civil and criminal matters.

He suggested that the local government administration would be shared with the municipalities and the rural authorities. The Local Authority would function as a corporation with technical experts controlling the staff. The affairs of the Local Authority to be directed by councils of elected representatives. The municipal authorities would provide social services such as schools, hospitals, police, prisons, courts, roads, water works, electricity and telephone. Azikiwe 
also suggested the separation of judiciary from the executive branch of the government. He drew up a long list of human rights. Among these rights were freedom of speech, freedom of the press, and the right to education up to the university level.

\section{$X$. CHIEF OBAMFEMI AWOLOWO'S FEDERAL PLANS}

Like Dr. Nnamdi Azikiwe, Chief Awolowo had plans about the Nigerian federalism. The Federation, according to Chief Awolowo, would unite the different cultural groups rather than separate them. It would also aid the various ethnic groups to advance economically, socially and politically at their own pace. This philosophy made Awolowo to divide the country arbitrarily into ten divisions based on ethnic groups. These units included the Hausas, the lbos, the Yorubas, the Fulanis, the Kanuris, the Ibibios, the Munshi, the Edos, the Nupes, and the ljaws. Each of these groups was to be a nation by its own right.

Dr. Azikiwe and Chief Awolowo contributed what in their opinions, would constitute a good Federal government. The suggestions they contributed, according to the above paragraphs, were clear indications of their influence and experiences gained in one way or the other, through the British Colonial Rule in Nigeria. 


\section{CHAPTER $V$}

\section{FEDERATION OF NIGERIA}

\section{JOHN MACPHERSON'S CONSTITUTION 1951-1953}

The first Governor who implemented some ideas toward self-government in Nigeria was Sir Bernard Bourdillon (see Chapter IV), but his proposals were put into practical use by Sir Arthur Richards in 1945. Richards' Constitution, however, made some sound progress as far as administration was concerned, but did not reflect advancement toward self-government since Nigerians were not included in the executive branch of the government.

In 1949, Sir John MacPherson succeeded Richards as the Governor. Partly because the Richards Constitution had been criticized and its details rejected by Nigerian leaders, and largely because Richards did not consult Nigerians, MacPherson, in formulating a new Constitution for the country, left it in the hands of Nigerians.

The preparation was undertaken on different levels in the country -villages, towns, districts, divisions, provinces and regions. Suggestions and recommendations from these levels were outlined on the provincial levels and discussed on the regional levels. 
In 1951, a Constitutional Conference ' was held in Ibadan, the capital city of Western region. The provincial and regional representatives were: Northern region -- The Sardauna of Sokoto -- Ahamdu Bello, Mallam Muhammedu Ribadu, Mallam Abubakar Tafawa Balewa, the Wali of Bornu, Shettima Kashim; Eastern region -- Mbonu Ojike, Alvan Ikoku, Eyo Ita, Sir Francis Ibiam; Western region -- C. D. Onyeama, Abu Bakr Olorun Mimba. Dr. Nnami Azikiwe did not attend because in his opinion, the meeting was not likely to lead to any radical reform. Among the most important matters discussed in the meeting were the following:

(1) Regional Boundaries

There was a wide variety of opinions as to the size of the regional units. While some provinces favored some modifications of the existing regions, others preferred regional boundaries to remain as were set up previously. Those in Calabar province, for example, were in favor of grouping along historical, cultural and ethnic lines. Onitsha province suggested that language, ethnic, and economic considerations be used. Warri, Benin and Owerri provinces preferred ethnic and linguistic to be the leading factors in deciding the regional units. liebu province advocated for the three natural divisional boundaries. Abeokuta, Bauchi, Bornu, Oyo, Ondo and the rest of the provinces chose to stay with the existing regions, but with boundary modifications which would aid the minorities

'Sir General Howe, the Attorney General, presided over the conference. 
to rejoin their kinfolks, should they so desire. For example, the Yorubas of Lagos and Ilorin would rejoin the Yorubas and the Ibos of Benin and Warri would rejoin the lbos in the East.

\section{(2) Regional Representation in the Central Legislature}

The question of representation brought much fear to the Southern delegates because the North numerical strength was heavier than that of the East and West put together. The population figures in the early 1950s were as follows: about $16,072,242$ for the North, about 7,669,867 for the East, and 6,005,931 for the West. The Northern representatives suggested that the principle of representation according to population be adopted. If this principle were followed, the North regional representation in the Central Legislature would be roughly 55 percent of the total members. The Eastern and the Western delegates maintained that federation meant equal representation. For this reason, the Eastern and the Western members held that each region was entitled to equal representation. It appeared that the Northern delegates were lenient in this issue. The end result was that representation was mutually agreed on 50 percent for the North and 50 percent for both the East and the West.

\section{(3) Revenue Allocation}

As in the regional representation, the Northern representatives wanted revenue allocation according to population while the South preferred allocation according to need and progress of each region. Eyo lta pleaded that the North be given a better and fair opportunity in revenue allocation. Eyo Ita's suggestion in 
effect meant that the least developed region should be given more money for development than the developed regions. No decision was reached on the method of allocation, but a commission was set up to study the problems and needs of each region and to make some recommendations regarding the methods of revenue allocation. Revenue allocation since independence is roughly 40 percent for the North, 33 percent for the East and 27 percent for the West. (Refer to Public Finance for details below.)

\section{(4) Regional Autonomy}

The majority opinion favored making the regions strong and the central government weak. The only counter opinion was that of Olorun Nimbe. He argued that strong regions and a weak centre in a sense meant that Nigeria was, in fact, three separate countries. He advocated for a strong centre, and weak regions because in his opinion, the only merit of the Constitution was its unitary characteristic. To depart from the point was to destroy that unity. Abubakar Balewa agreed on strong regions only as a temporary measure to be reversed when the North could match with the East and West. 2

\section{(5) Ministerial Responsibility}

When the questions of representation and allocation of revenue were discussed, the South feared the numerical power of the gigantic North. Here the position was revers ed. The North, with limited educational opportunities, feared

\footnotetext{
${ }^{2}$ Richard L. Sklar, Nigerian Political Parties (U.S.A., 1963), p. 99, footnote "26.
} 
the superiority of the South. Their fear was that the South was likely to excel or demonstrate superiority over them in experience and management of a parliamentary government. While the Eastern and the Western delegates advocated for the introduction of ministerial responsibility in the regions and at the centre, the Northern representatives were not in a position to support the idea. The only Northern delegate who spoke on the issue was Hon. Abubakar Tafowa Balewa.

\section{A BRIEF BIOGRAPHY OF ABUBAKAR TAFAWA BALEWA (1912-1966)}

Balewa, who became the first Prime Minister of the Federation of Nigeria in 1960, was born in 1912, in a small town district of Lere, in Bauchi Emirate. His tribal origin is Gerawa, a habe tribal group to which the royal family of Bauchi belongs. He was educated at the Bauchi provincial school 1925-1928 and attended the Katsina Teacher Training College in 1928-1933. After graduation, he became a teacher, and later, was made the headmaster at the Bauchi Middle School. He was one of the founders of the Famous Bauchi Discussion Circle. ${ }^{3}$ In 1945-1946, he studied for a Teacher's Professional Certificate at the London University Institute of Education. On his return to Nigeria, he was chosen by the Bauchi Native Authority to represent that Native Administration in the Northern House of Assembly, and by the latter body, as a Northern member of the reconstituted Nigerian Legislative Council. There, he disputed the claim of the

3 It was discussion groups of educated young men in Northern Nigeria, initiated by a British Resident. The Secretary was Aminu Kano. 
N.C.N.C. London delegation to speak for all of Nigeria and expressed his own belief that independence would not be a feasible object for Nigeria until a significantly greater measure of national unity had been achieved. In 1948, he was elected a Vice President of the Northern Teachers' Association. He was very active in the review of the Constitution at all levels and emerged as the most important spokesman of the common views of the majority of the people of the North at the Ibadan General Conference of January 1950. He presided as Prime Minister over the National Government and was knighted in 1959. He was assassinated during the 1966 military coup.

He did not object to the introduction of a ministerial responsibility in the East and in the West. His main argument was that the North was not ready to shoulder ministerial responsibility. For that reason, he did not sanction it in the North or in the centre. He suggested that the East and the West were free to experiment it for five years. ${ }^{4}$ The Northern rejection of the introduction of ministerial responsibility in the region, in the opinion of the author, meant that the North was not adequately equipped with the knowledge of administrative government as the East and the West. In other words, they were not ripe enough for self-government. When self-government was finally granted to the East and the West in 1956, that of the North was postponed until 1959.5

$$
\begin{aligned}
& { }^{4} \text { Sklar, Political Parties, p. } 87 . \\
& { }^{5} \text { Smith, Recollections, p. } 389 .
\end{aligned}
$$


MacPherson's Constitution in effect established as a central legislature a House of Representatives. It also set up bicameral legislatures in the North and the West and a single chamber in the East (see Figure 4). It gave the regional governments authority over the local government, education, health, agriculture, fisheries, forestry, direct taxation excluding income and company taxes, Native Courts, subject to central legislation with regard to appeals, public works and town and country planning. A regional bill became law if it was approved by a lieutenant-governor or the Colonial Secretary. If the Governor so desired, a regional bill could be debated in the House of Representatives.

The Northern House of Chiefs comprised a lieutenant-governor, all firstclass chiefs, thirty-seven other chiefs, and one member who acted as adviser on Moslem law. The Northern House of Assembly consisted of the President, appointed by the lieutenant-governor, ninety elected members and ten special members appointed by the lieutenant-governor to represent other interests or communities not adequately represented. In the regions of Nigeria, including the Federal Capital, Lagos, European merchants, missionaries and industrialists were to be adequately represented in the House of Representatives and in the Regional House of Assemblies. They were the interest groups or communities not adequately represented. The executive council was made up of the lieutenant-governor as the president, three ex officio members, two officials and regional ministers. The Joint Council of the House of Assembly was created. The duties of this council included performing of such duty as electoral college, electing representatives from the regional legislature to the Central House of Representatives; ratification 


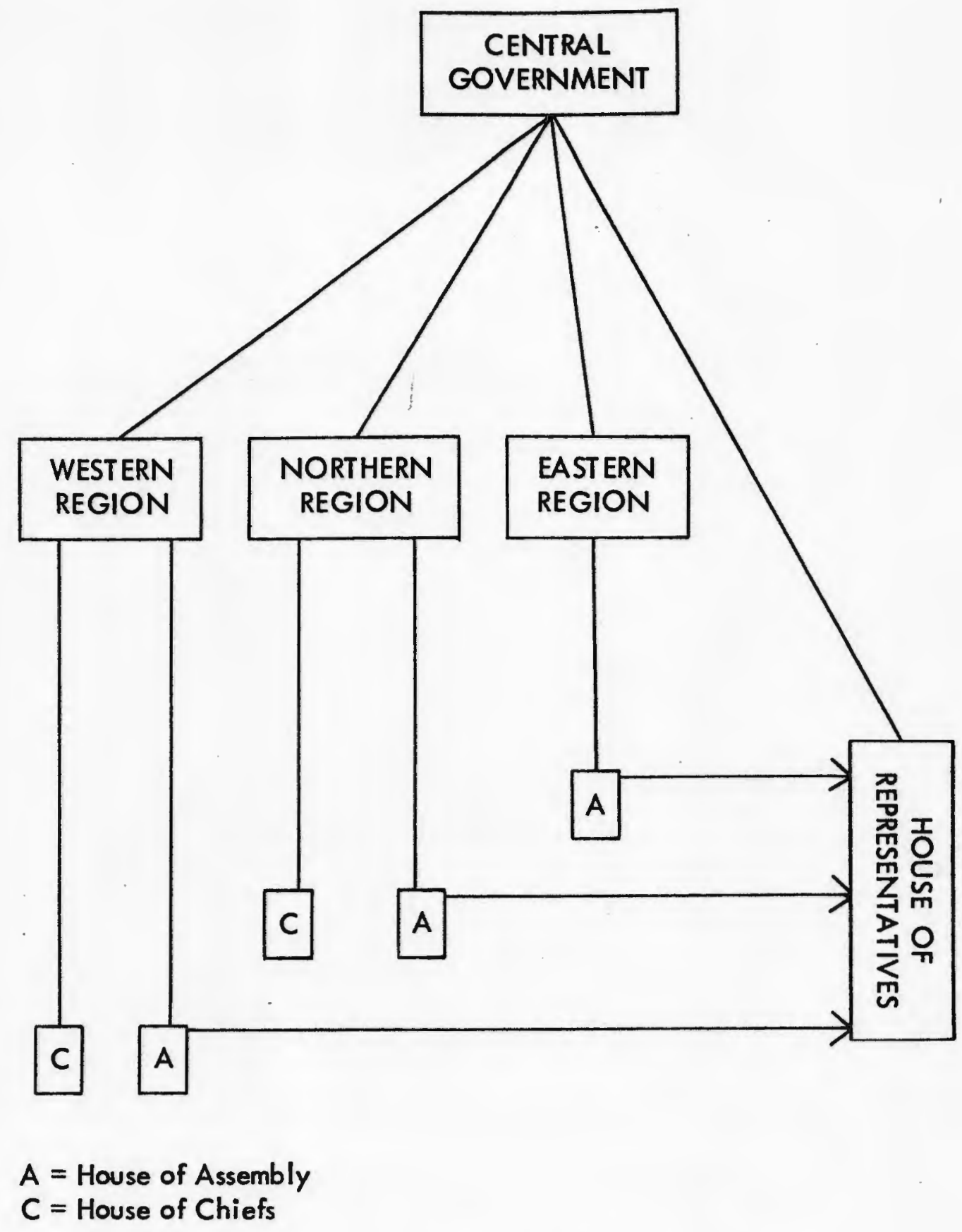

Figure 4. Nigeria Legislature 1951 
of the appointment of a member as a federal minister. The council consisted of twenty members with the lieutenant-governor presiding.

In the Western region, the House of Chiefs was made up of the lieutenantgovernor who acted as the president, three officials appointed by him and about fiffy chiefs and local chiefs. The House of Assembly included a president, and four officials appointed by the lieutenant-governor, eighty elected members, and three others representing other interests. The Joint Council of the Western Region was similar in structure and function to that of the Northern region, but did not serve as electoral college.

In the Eastern region, the House of Assembly consisted of the lieutenantgovernor as the president, five officials, eighty elected members, and about three other members representing other interest groups not sufficiently represented. The executive council comprised the lieutenant-governor acting as the president, ex officio and official members were as in the Western and the Northern regions.

The Central Legislature comprised a president, six ex officio members, 136 representative members and six special members appointed by the Governor to represent interests and communities such as commercial, industrial and religious groups.

Elected members numbered 136. Of this number, the Northern elected members were sixty-eight, thirty-one members came from the Western regional House of Assembly, and three from the Western House of Chiefs. The Eastern House of Assembly elected thirty-four. Representatives to the regional legislature were elected by electoral colleges which were established in primary elections. 
All adult male taxpayers were given the right to vote in all primary elections and elect members to the Regional House of Assemblies.

In addition, the Constitution established a Public Service Commission whose duty was to advise the Governor on matters affecting the Public Service. ${ }^{6}$ With the MacPherson Constitution, the Native Authority ceased to function. As from that date, the Native Authorities were responsible to the people through the $\mathrm{Ni}$ gerian ministers. It was with the Constitution that the real and meaningful partnership started between Nigeria and Britain: the Constitution made provision by creating opportunities for Nigerians to be trained in the art of modern government. ${ }^{7}$ The Constitution also provided the best way of proceeding to the parliamentary administration as a single unit. Unfortunately, Chief Awolowo and Sardauna of Sokoto, Sir Ahamdu Bello preferred to remain in their own regions. 8 The Constitution, therefore, did not work as a single unit. It also did not clearly fall into federal pattern in the real sense of it. Section 92 of the Constitution gave power to the Central Legislature to delegate legislative power to regions on any matter in which the Federal Government itself had competence.

If all the political leaders had accepted to make the centre strong and the regions weak, the author is of the opinion that the parliamentary form of government so established, would be such that would guarantee greater freedom for the

$$
\begin{aligned}
& { }^{6} \text { Burns, History of Nigeria, p. } 252 . \\
& 7 \text { Awolowo, People's Republic, p. } 47 . \\
& { }^{8} \text { Mackintosh, Nigerian Government, p. } 26 .
\end{aligned}
$$


individual or a collective freedom for the people as an organized whole. Also, the political parties which came into being and which became the only instrument for nationalism would be nationalistic in form and outlook. 9

Others, mainly political leaders, believed that the Constitution tied the regions too closely to the centre, and through the electoral college system, it made it possible for dual memberships for some members. They also believed that it made it difficult to dissolve any of the Regional Houses of Assembly without endangering the lives of the other legislatures in the country. To them, the Constifution made no substantial advance toward self-government. The powers given to the Nigerian ministers were, in their opinion, insubstantial. They were given charge of certain matters such as education and agriculture but did not head departments and there was no provision for a premier for each regional government. They argued that even in the Central Legislature, the ministers were denied any ministerial responsibility. The Central Executive Council, which still included six Europeans, senior ex officio members, was presided over by the Governor. For these reasons, they maintained that it was all fuel for agitation over the question of a full self-government.

In 1953, the leading Southern leaders proposed a federal system which would allocate specific powers to the central government and leave all others to the regions. All the regional governments were required to adopt the British

${ }^{9}$ Nearly all major political parties -- Northern Peoples Congress and the Action Group -- are tribalistic; National Council of Nigeria and the Cameroons have this characteristic too. 
pattern of Cabinet parliamentary government. The Central Executive Council was still to comprise a fixed number from each region. Following this proposal, a London Conference was summoned with a view to working out more details of the Constitution and, in addition, settle the status of Lagos. There were altogether nineteen delegates and thirty-nine advisers. Dr. Azikiwe, Chief Awolowo, Sir Bello and Sir Balewa were all present. For three weeks, ${ }^{10}$ the general discussions and proposals centered on territorial divisions, organization of federal government, regional organization, regional self-government, and the status of Lagos.

For territorial division, Nigeria obtained the status as a federation consisting of the three regions and the Federal territory of Lagos. The Southern Cameroons was made a small region.

The Chief Executive of the National Government was the GovernorGeneral. The executive body was still the Council of Ministers, consisting of ten elected members, three from each of the regions and one from Southern Cameroons. Six of the ministers headed some departments.

In the Northern region, the Governor was the President of the Executive Council. Other members included three ex officio members, the Civil Secretary, the Attorney General, the Financial Secretary and thirteen regional ministers of whom one was a premier. The Northern legislature was bicameral. The House of Chiefs was made up of the Governor who was the president, all first-class chiefs

${ }^{10}$ The Conference lasted from July 30-August 22, 1953. 


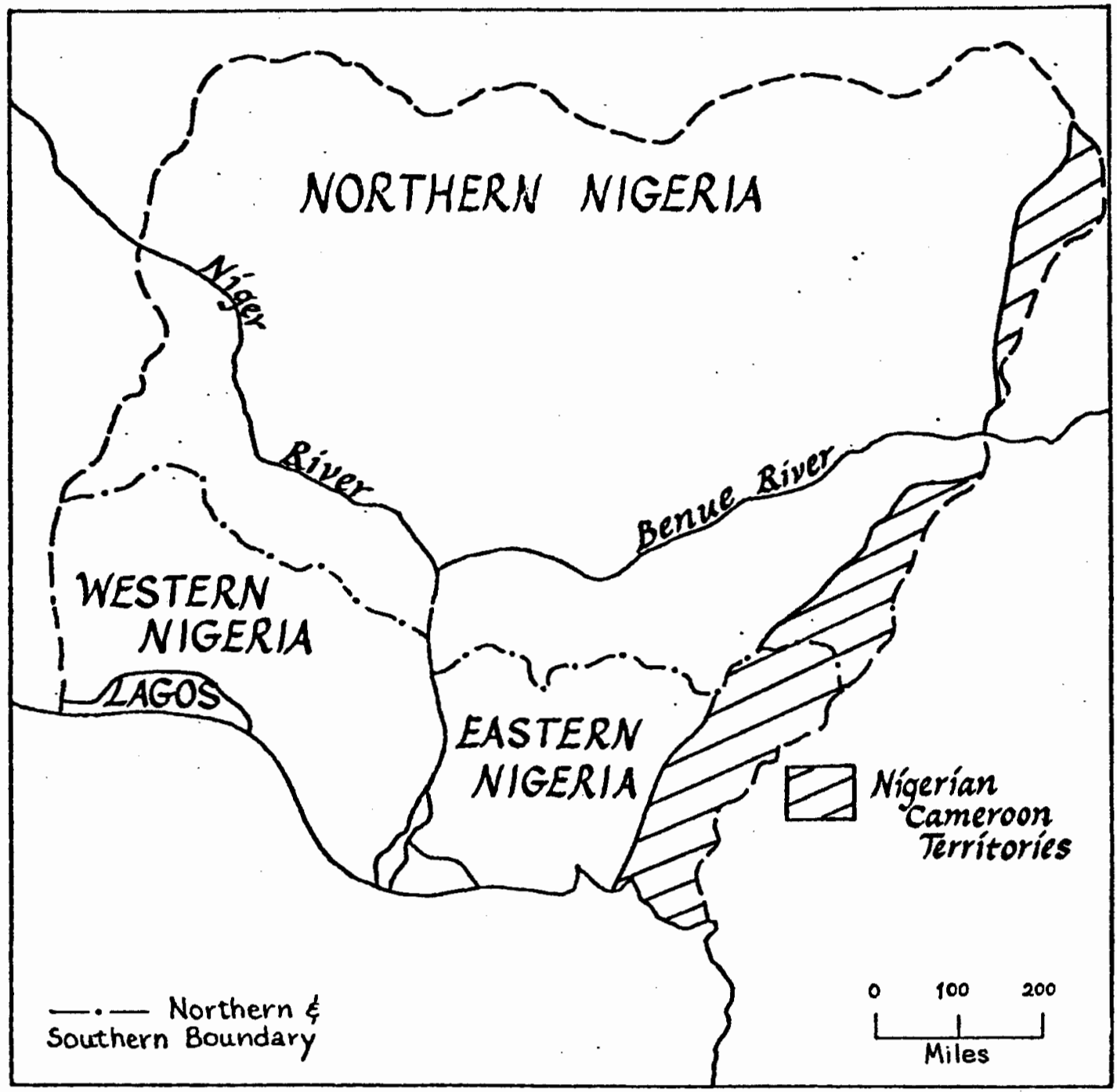

Figure 5. Federation of Nigeria. 
and thirty-seven other chiefs. The composition of the House of Assembly was not altered.

For the Western region, the executive council was made up of the Governor who was the president and about nine ministers, one of whom served as a premier. The legislature was still bicameral. The House of Chiefs consisted of a president elected from among the members, about fifty head chiefs, plus other chiefs, members of the executive council and four members representing special interests. The House of Assembly comprised: a speaker, eighty elected members and three members representing special interests.

The Eastern region followed the same pattern except that the legislature was not bicameral and the elected members to the House of Assembly were eighty-four.

In all the regions, the executive council had the same function as the executive organ in the Cabinet system of government. The Governor appointed a premier of a region. The Governor was to consult the executive council and accept its advice.

Britain was not willing to grant self-government in 1956. The reason was that the Northern pre mier preferred to delay that of the North until they were ready for it. However, the Colonial Secretary finally promised to grant selfgovernment to any region that would ask for it in 1956.

At the meeting, all the regional leaders unanimously favored strong regions. Since 1951, the leaders had been taking a firm stand on strong regions. It could be assumed that they pressed hard on strong regions for personal gain, 
although Dr. Azikiwe's personal view was that he preferred a strong region as a means of bribing the North and persuading the Northern People's Congress to cancel its "Custom Union Proposal."

On the status of Lagos, all the leading members gave their views which ranged from loosing Lagos to the Western region to building a new capital. Despite the differences of opinions, Lagos assumed a new status as the Federal Capital of the country.

\section{THE LYTTLETON CONSTITUTION, $1954^{12}$}

A resumed constitutional conference was held in Lagos in January 1954 with the Nigerian leaders in attendance. The below shows the summary of effects of the conference: (1) The Governor of Nigeria became the Governor-General while the lieutenant-governors became full governors. The leading ministers in each region became premiers. ${ }^{13}$ The regional legal secretaries became Attorneys General and Governors dealt directly with the Secretary of States except in federal matters. (2) The British officials were replaced by Nigerians in the Eastern and Western Regional Executive Councils while the North kept all the British officials

"This was eight-point program of N.P.C. It would lead to the breaking away of North from the rest of the country, e.g., there should be no Central Legislature body and no central executive or policy-making body fro the whole of Nigeria.

12 Lyttleton, who was on a visit to Nigeria, was made the chairman.

13 Bello became premier of Northern region, Azikiwe, premier of Eastern region, and Awolowo, premier of Western region. 
except the two Residents. (3) Lagos was administered separately as a Federal Capital. (4) All the regional governments had their own High Courts of Justice and their own Public Services. Powers of the regional governments were extended at the expense of the central government. 14 (5) The House of Assembly was created for Southern Cameroons.

In 1957, a resumed London Conference was summoned with all the Nigerian premiers present. The conference was not a constitutional conference. But, rather, it was an Independence Conference. However, two minor but related issues were raised. One was the creation of more regions, and the other was the minority fears (refer to Chapter VI). All the Nigerian leaders pressed that Nigeria was capable of managing its responsibilities. For this reason, the leaders requested independence to be granted in 1960. The final result was that the British government assured the leaders that independence would be granted in 1960, if all the leaders would unanimously ask for it.

Since Britain took over the administration of Nigeria, her government had been making reasonable contributions to the advancement of Nigeria. Between 1903 and 1905, grants-in-aid from Imperial Treasury for Northern Nigeria amounted to four hundred five thousand pounds. Between 1899 and 1913, her total expenditure including the money paid to the commercial companies, totaled about four million pounds. In January 1927 the British government gave a loan of over four million pounds at the interest rate of 5 percent for the development of

$$
{ }^{14} \text { Smith, Recollections, p. } 422 .
$$


Nigeria. In 1945, the British government gave a grant amounting to three and a half million pounds for the new University College Ibadan, Nigerian College of Arts, Science and Technology. 15 Here, the government is pictured as taking a number of stands on Nigerian major constitutional issues. But, at the same time, accepting the decisions of Nigerian leaders. ${ }^{16}$ To put it another way: it illustrates the overall concern of the British Colonial Government on one hand, and the Nigerian political elites on the other hand, conscientiously planning for a better future of Nigeria. The Constitution had Nigerian stamp.

\section{N. POLITICS}

Politics in Nigeria originated out of the value of western education. It became the major source through which Nigerian political leaders came to learn and understand more and more about government of Nigeria.

The oldest, but short-lived established political party in Nigeria was the Nigerian National Democratic Party (NNDP). It was founded in 1922 by the late Herbert Macaulay and was supported by the leading national ists of which John Payne Jackson was one of them. The main function of this party was to elect Lagos members to the legislature.

The National Council of Nigeria and the Cameroons (N.C.N.C.) party which was so named in 1945, grew out of another union. The Nigerian Union of

\footnotetext{
${ }^{15}$ Nicolson, Administration of Nigeria, p. 258.

${ }^{16}$ Mackintosh, Nigerian Government, p. 29.
} 
Students (N.U.S.) which comprised the National Reconstruction Group (N.R.G.), Dr. Azikiwe, M. E. R. Okorodudu, E. E. Esua and L. A. Onojobi were members; the Nigerian YouthMovement (N.Y.M.), Dr. K. A. Abayomi and Ernest Ikoli were prominent members, the Nigerian Youth Circle (NYC), H. O. Davis and J. M. Udochi were organizers; the Nigerian Union of Students (N.U.S.) with P. N. Malafa, Ransome Kuti as active members. Influential members in the N.C.N.C. included Rotimi Williams, H. O. Davis, Herbert Macaulay and Dr. Nnamdi Azikiwe. Dr. Azikiwe was the general secretary while Herbert Macaulay was the president. 17

The Northern People's Congress (N.P.C.) took its root from Northern Teachers' Welfare Association (N.T.W.A.) organized in London by Northern students between 1945 and 1946. The organizers included Malam Abubakar Tafawa Balewa, then a student in London, and Malam Aminu Kano who was the secretary. $^{18}$

The Action Group (A.G.) party of the Western region emerged from the old Pan-Yoruba Cultural Organization established in London with the title, "Igbe Omo Oduduwa." Influential members were Chief Bode Thomas who studied law in England in 1940-1942 and Chief Obamfemi Awolowo who also was educated in London. In 1951 the Action Group announced itself to the nation as a Western regional political organization. ${ }^{19}$

$$
\begin{aligned}
& { }^{17} \text { Coleman, Nigeria, p. } 264 . \\
& { }^{18} \text { Sklar, Political Parties, p. } 91 . \\
& { }^{19} \text { lbid., p. } 105 .
\end{aligned}
$$


From 1947 to 1960, political events in the whole country moved increasingly toward giving much weight and power to the regions. Two principol factors were and still are responsible for this. First, the concentration of different tribal elements in separate regions had a powerful influence on the development of regional consciousness. Second, owing to the increasing political development, the tribal loyalties had also been transformed to a common political organization. ${ }^{20}$ And finally, although religious beliefs did not play important role in the Eastern and Western regions, its role in developing the desire for a measure of regional independence was felt more in the Northern region since there was a powerful, coordinated concentration of Moslems in the Northern section of the region. $^{21}$ In 1953, all the four leading political leaders -- Dr. Nnamdi Azikiwe, the leader of the N.C.N.C., Sir Ahmadu Bello and Sir Abubakar Balewa, the leaders of the N.P.C., and Chief Obamfemi Awolowo, the leader of the A.G. -- attended the London Conference. The most urgent matter discussed was how regional autonomy could be effectively combined with the central government. 22 The effectiveness of this lies in the allocation of specific powers such as customs, foreign policy and defense to the Federal Government and making regional governments answerable to the Federal Government in such areas as taxation and communications. The same Nigerian leaders met again in 1954 in Lagos under the

${ }^{20}$ The Nigerian Geographical Journal 2: 7.

21 bid., p. 8.

${ }^{22}$ Mackintosh, Nigerian Government, p. 27. 
chairmanship of Lyttleton and requested for strong regions at the expense of the Federal Government. Subsequent conferences met all the leaders actively participating in political matters. For example: before the 1959 general election into the House of Representatives took place, all the political leaders requested the Governor-General for a bill on human rights. This request did not necessarily mean that there was no freedom or right whats oever. There was freedom of speech, freedom of press and the right of ownership. The leaders wanted the bill on human rights to be enacted into law so as to facilitate the campaign process. Also, since the Nigerian political thoughts and their institutions have English elements, they wanted the human rights to be embodied in the Constitution as common law. The law in operation in Nigeria today is a combination of the native law, the Moslem law, and the British law which was transplanted in Nigeria during the British Colonial administration. ${ }^{23}$ For instance, the wise saying that any individual who is charged with criminal offense shall be presumed innocent until such individual is proved guilty according to law, was transplanted from Britain into Nigeria. Also, any person who is charged with a criminal offense has the right in Nigeria, as in Britain, to be informed immediately, the nature and the causes of the accusation against him. He has the right to defend himself either in person or through legal assistance of his choice. All Nigerian courts which try a person for criminal offenses have to keep records of the proceedings as well as the judgments of the courts. Even the law which makes

${ }^{23}$ Awa, Federal Government, p. 120. 
capital punishment possible in Nigeria was transplanted from Britain. Today, capital punishment is enforced in Nigeria.

In 1958, the Nigerian political leaders unanimously requested the British Government to adopt a universal adult suffrage for all the regions. This was to be applied in the 1959 General Election. In the Eastern and the Western Nigeria, men and women participated in voting and electing members. In the Northern Nigeria, women were denied this voting right on the ground that Moslem law forbade their women to take part in politics. 24

In the same year, a new electoral law was introduced. The law made it possible for elections to be conducted by secret ballot. The secret ballot system was a methodology transplanted into Nigeria from England. It replaced the "whispered" votes, which gove the illiterate voter the right to whisper the name of the candidate of his choice to the polling officer. It was also a substitute for the method of a "show of hand," which was misused at times by the polling officers. The secret ballot system has come to stay in Nigeria since then. It has become the only democratic means of electing officers or members into offices.

Although the political parties in Nigeria assumed different characteristics from that of Britain, politics was one of the western forms of institutions which had the deepest influence in the country. The parties were properly organized. They were the only agencies which won power at all political levels. The

\footnotetext{
${ }^{24}$ The position of Northern women has not changed as far as politics is concerned.
} 
winning and keeping, or holding of power, had the same western characteristics, in the sense that set down rules of procedures were followed.

\section{CIVIL SERVICE}

The Nigerian Civil or Public Service was a part of the Colonial administrative organizations which gave Nigerians a wealth of experiences and influence in administrative government.

In the early days of the Colonial history, Public Services were directed at the headquarters in Lagos through the Residents of each province. Where Africans were used, they were not Nigerians. The staff was recruited from the Gold Coast and Sierra Leone. ${ }^{25}$ By 1920 s Civil Service was organized as a single service by Sir Donald Cameron, the head of the Secretariat, throughout the country, still with headquarters in Lagos. Richards' Constitution strengthened this unitary system for the purpose of unity of the country and for adequate services. Furthermore, the unitary system cut down administrative expenses and to a certain extent, allowed more Nigerians to participate in the administration.

In order to create more opportunities for Nigerians, and to perform more effective services, three administrative centres were created, one for each region. Each of these regions was empowered to set up a regional council which handled administrative responsibilities such as recruitment of officers.

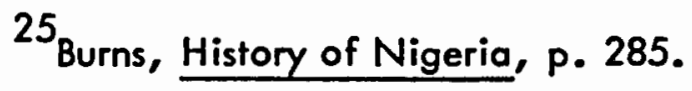


Between 1946 and 1954, the central and the unitary character of the Civil Service was modified by giving regional service power to appoint, promote and control its civil servants. Many public services which appeared to be countrywide were, in fact, regional services in practice. By 1954, when the country became a federation, the Civil Service ceased to maintain its unitary characteristics. Instead, three regional Civil Services were created. Each regional Public Service was autonomous. This "regionalization" of Public Service was in part the demand of the Colonial government as a means of providing more opportunity for Nigerians to gain more experience in the field. It was also the wish of the party leaders, who wanted to learn more about how to control and master their own regional Civil Service. A good understanding of the Civil Service would enable the leaders to manage the same machine in an independent Nigeria. ${ }^{26}$ The step also brought about "Nigerianization" of the Civil Service, especially in the Eastern and in the Western Nigeria. 27

It would be an error on the part of the readers to think that at this time the Nigerian Civil or Public Service was completely controlled by Nigerians. For, in the North, nearly all senior posts were still in the hands of the British officials. Even in the East and West, some British officers acted as advisers. The point of emphasis is that sufficient chances were given to Nigerians to understudy the British administrative officers.

$$
\begin{aligned}
& 26 \text { Nicolson, Administration of Nigeria, p. } 280 . \\
& 27 \text { lbid., p. } 281 .
\end{aligned}
$$


Since 1943, Dr. Nnamdi Azikiwe had protested against importing officers into the higher rank of the Nigerian Civil Service. He had also proposed sending a thousand Nigerians for the first ten years to be trained in various administrative fields. His aim was that in the future, Nigerians might be appointed to the key posts. At that time, the British expatriates would act temporarily in the advisory capacity. In 1948, MacPherson appointed a commission to make recommendations about the recruitment and the training of Nigerians for the government Senior Service. Dr. Azikiwe was one of the eight Nigerians who sat on the commission. ${ }^{28}$ The commission recommended that where a suitable Nigerian was available, he should be preferred to a British expatriate for recruitment. At the same period, Dr. S. L. Manuwa, who was in charge of directing Medical Service, was appointed with three others to the executive council. The commission also made it possible for some Nigerians to be trained at Ibadan University. By the middle of 1948, there were about 3,786 posts in the higher Public Service of Nigeria. Of these posts, about 1,245 posts were vacant, 245 posts were occupied by Africans. Nigerians, Sierra Leonians, and some people from the Gold Coast were appointed. In Medical Department there were 75 Africans and 303 expatriates. A further step was taken in 1955 toward Nigerianization of the Federal Civil Service. It involved preliminary, intermediate and senior training of Nigerians by the Federal Government. The Government created a post of Nigerianization Officer, whose duty was to carry into effect the project of

${ }^{28}$ Crowder, Short History, p. 276. 
Nigerianization and of coordinating the work of the Public Service Commission, the establishment Branch of the Ministry of Finance, and the Scholarship Branch of the Ministry of Education. This office was given to a Nigerian. ${ }^{29}$ This further step was, in fact, a del iberate act of Her Majesty's Government in her task of nation-building. The United Kingdom Government in 1954 asked the British officers to further the progress of Nigerianization. In addition, the Government issued a policy statement on the reorganization of the Colonial Service. For example, the British officers were to be given adequate notice of any intention to terminate their appointments in consequence of changes in the Constitution. The United Kingdom Government promised to employ these officers in Britain. It also made it quite clear that adequate compensation would be given to those officers by the government of the regions concerned, in the event of retirement, owing to changes in the Constitution.

The structure of the Public Service in the centre and in the three regions followed the same pattern. Each was divided into three broad divisions: (1) the General Service classes, comprising the administrative class, the general executive class, the secretarial class and the clerical, messengerial and miscellaneous classes; (2) the Specialist classes, which consisted of people with a wide range of professional, scientific and technical qualifications; (3) the Departmental classes which were made up of posts which were peculiar to a particular department. All the heads of the regional governments adopted the same pattern in the post-

${ }^{29}$ Awa, Federal Government, p. 168. 
independence. In the Western region, for example, Chief Awolowo increased the Western ministeries from twelve to nineteen. ${ }^{30}$ This was a move made by Chief Awolowo and approved by the Governor to accommodate his party colleagues. It was also to give an opportunity for more Nigerians to gain experiences in the ministerial government.

\section{FOREIGN POLICY}

Experience in foreign affairs started when Britain signed treaties with the Delta States of Nigeria between 1830-1885. The purpose of these treaties was to stop slave trade. When Britain finally occupied Lagos territory, foreign relationship became that of a master and a servant. This knowledge of foreign affairs was reflected in most of the Nigerian leaders.

In 1949, Dr. Nnamdi Azikiwe recalled to mind that Africans had been called upon to participate in the Second World War. He was contemplating on whether Nigerians should align with the western powers or with the eastern bloc, or whether she should adopt the policy of neutrality. In 1955, Dr. Azikiwe also attacked Afro-Asian States for inviting the Gold Coast, and not Nigeria, to the Bandung Conference. His interest in foreign affairs was observed in 1958 in Accra, where Pan-African Conference was held. His speech below clearly reflected interest in foreign affairs:

${ }^{30}$ Adedeji, Nigerian Administration, p. 6. 
We are on the eve of great events. A future Federation of Independent West African States had made a beginning. It is my earnest hope that the Federation of Nigeria, soon to be independent, will play a worthy part in the Larger Federation. 31

The idea of the West African Federation came from the British officials who were in Nigeria, the Gold Coast, and Gambia. It was the wish of the Fathers of the W.A.F. to promote unity of West African people.

After the resumed consitutional conference in 1958, Nigerian leaders embarked upon an increasing participation in formulating foreign policies. This also was through the instrumentality of the British officers. The reason for the increased participation was to make foreign policy an issue in the 1959 Federal election. Before the 1959 Federal election, all the political leaders -- Dr. Nnamdi Azikiwe, the leader of the N.C.N.C. and Premier of Eastern region; Chief Awolowo, the leader of the A.G. and Premier of Western region -- resigned from the office of Premiership to seek Prime Ministership at the centre, by running for Parliament. The offices of Premiership in the East and West were therefore filled by Dr. M. I. Okpara and Chief Akintola, respectively. 32 In the North, Hon. Abubakar Tafawa Balewa, the deputy premier, was asked to run the election because Sir Ahmadu Bello preferred to hold the office of Premiership. (1964), p. 13.

${ }^{31}$ Claude S. Phillips, The Development of Nigerian Foreign Policy

${ }^{32}$ Chief Akintola was killed during the 1966 coup, while Dr. Okpara was spared. 


\section{A BRIEF BIOGRAPHY OF SIR AHMADU BELLO}

Alhaji Ahmadu Bello, the Sardauna of Sokoto, was a direct descendant of Shehu Usuman Dan Fodio, the founder of the Fulani Empire. He was born in 1910, in Rabah in Sokoto province, where his father was a district head. He received his education at the Sokoto Provincial School. He attended the Katsina Teacher Training College and served as a teacher of English and Mathematics at the Sokoto Middle School, between 1931-1934. Later, he served as a district head of Rabah in 1934-1938. In 1938, he was appointed Sardauna. ${ }^{33}$ This appointment was due to the death of Sultan Hassan in 1938. In 1945, when the Youth Social Circle was formed, he supported the movement and when the party affiliated with the Northern People's Congress, he became the patron. He went to England on the tenth of January 1948 to study local government. ${ }^{34}$ When the Wazin $^{35}$ of Sokoto died in 1949, Bello was chosen to take his place as the representative of Sokoto province in the Northern House of Assembly. During the MacPherson constitutional review, he emerged as an important personality, defending the Northern regionalism. He became the first Premier of Northern Nigeria on October 1, 1954. He was one of the victims of the 1966 coup.

Before the election, all the leading Nigerian leaders had formulated their own foreign policy views. All of them agreed to make Nigeria a member country

${ }^{33}$ Sardauna is a title meaning the leader of war.

${ }^{34}$ Sir Alhaii Ahmadu Bello, My Life (London, 1962), p. 64.

${ }^{35}$ Local title for Premier or principal officer in the North. 
in the Commonwealth of Nations as well as in the United Nations. They also accepted to continue friendly relationship with the United Kingdom as well as the United States. $^{36}$ The three leaders promised to strengthen kinship with the African States with special reference to the West African countries. Dr. Azikiwe emphasized the encouraging of foreign investments and promoting and strengthening of Nigeria armed forces. Chief Awolowo stressed on cooperation with the western bloc so long as their policies were consistent with the national sovereignty and interest of Nigeria. In the same token, the N.P.C. leader, Sir Balewa, ruled out the policy of neutrality. He promised to make Nigeria a member of the Commonwealth, to have closer ties with the United Kingdom and United States of America. He also promised to continue friendly relations and closer cooperation with all African countries with particular reference to the West African countries. On the twentieth of August 1960, which was the last session for the members in the Nigerian Parliament or the House of Representatives before independence, the Prime Minister, Sir Balewa, made it abundantly clear that his government's policy was that of befriending all countries which were members of the United Nations. He also made it quite clear that it was his duty at all times to safeguard and promote the interest of the Federation and its citizens in foreign affairs.

After independence, Nigeria did not depart from these policies. She established friendly relationship with all countries which sought Nigeria interest, ${ }^{36}$ Awa, Federal Government, p. 264. 
such as United Kingdom, United States and France. She had not interfered with internal affairs of any nation, no matter how small or weak.

\section{PUBLIC FINANCE}

Before the coming of Britain, the Northerners had been paying a type of petty taxes in the form of alms fixed in proportion relative to the nature and quantity of their property. These taxes were paid to their rulers, who did not put all the money so collected into public use. Evidence available does not show that there was an organized form of taxation in the West and none at all in the East.

General taxation was first introduced in the North by Lord Lugard when he raised a local revenue in order to be able to carry out his duties. For instance, he needed to pay for the construction of roads and railways in the Lagos locality. He needed money to pay to his officers. Taxation in the North took different forms: land taxation was assessed by the British officials to a community on the land the people occupied. A jangali, a tax payable by nomads or herdsmen on the profit made by the sale of their animals, was another form. In the backward areas of the North, poll tax was paid. The proceeds of the general tax and the jangali were divided between the British and the Native Administration. 37 In some settled areas, the proportion of sharing was fifty-fifty. In an unsettled area, 15-20 percent went to the village head and the government took the rest. Taxation on European traders was in the form of leases and licenses for mining. In

\footnotetext{
${ }^{37}$ Sir Williams Geary, Nigeria Under British Rule (London, 1965), p. 235.
} 
1913, a revenue of about two hundred seventy-four thousand seventy-eight pounds, in the general taxation of the natives, was collected. In the same year, a total of twenty-nine thousand two hundred eighty-one pounds was collected through business enterprises.

In the South, custom duties which were assessed by the British officials were in operation since 1906. General taxation in the Western region was introduced between 1917 and 1920. In the East it was introduced in 1925. There was resentment in the East because the people wrongly believed that its introduction was an attempt to hand over their lands to the government. In 1929, it was mistakenly assumed that women in the East were going to be assessed or taxed. The unfounded fear brought a serious women rising at Aba, Owerri and Calabar provinces.

For awhile, revenue collection in the South was from land. Even then, it was the Native Authority who kept the money. This policy of keeping the revenue out of the government's reach deprived the government at Lagos from getting its share. In 1927, Governor Sir Graeme Thompson suggested that receipts from direct taxation be shared between the Native Authority and the government in the ratio of $70: 30$. Further improvement on the revenue sharing was made by Sir Bernard Bourdilion who requested that the government must retain the right to reapportion taxes on times of financial distress. This suggestion, however, was to maintain reasonable balance of revenue sharing. By the 1930s, the regional revenue resources came from licenses for and taxes on duty, liquor, motor vehicles and drivers; forestry, rents on mining rights and leases; court fees; water 
supply undertakings, and direct taxation. The revenue of the central government came from custom duties and it was hardly enough to pay for its services.

In the 1940s, direct taxation on individual basis was started in Logos. The government and the commercial employees were assessed. Four and a half pence in the pound was assessed on income up to seventy-two pounds. Those individuals whose income exceeded seventy-two pounds were taxed sixpence on the pound. By 1950, the rate jumped to one shilling tax on income between four hundred and seven hundred pounds. One shilling and sixpence was the fax for income brackets of seven hundred to one thousand pounds. Two shillings was assessed on income falling between one thousand and two thousand pounds. Beyond this amount, extra one shilling tax was paid. In all cases, family was taken into consideration. In other words, if "A" and "B" were on the same salary scale, but "B" had no family, "B" paid more tax than "A."

In the South, all those who earned minimum amounts paid two shillings per head. In the East, people with, soy, seven hundred pounds a year, were assessed four and a half pence. In the West, this rate jumped later on to six or eightpence. It was believed that the same general principle was adopted in the North. On the whole, the general principle of P.A.Y.E. ${ }^{38}$ was adopted in the 1950 s in the regions.

Regional revenue paid to the centre was done on the basis of population: the North paid 36 percent with 59 percent of population; the West paid 26 percent ${ }^{38}$ P.A.Y.E. means pay as you earn. This principle is still in operation. 
with 18 percent of population; while the East with 23 percent of population paid 38 percent of the revenue.

The central government then paid block grants to the regions, according to derivation and progress. This method was found to be unsatisfactory, since it did not take into consideration other factors, like need. With this method, the North received relatively small share.

Dr. Nnamdi Azikiwe, addressing his party members in 1955, at Enugu, in Eastern Nigeria, suggested that the revenue of the Federation ought to be allocated according to needs, even development and derivation. ${ }^{39}$ His suggestion in a large measure would allocate reasonable amount of revenue to each region at the expense of the centre.

Several other suggestions on revenue allocation were made by HicksPhillipson and Raisman Commissions. Hicks-Phillipson Commission recommended that grants based on population be allocated to regions and that regions ought to control their own regional revenues. The Raisman Commission based his recommendation on needs, population, and balanced development. With these principles, the government allocated 40 percent of the central revenue to the North, 24 percent to the West, 31 percent to the East, and 5 percent to the Cameroons 40 (changed to $\frac{40}{95}, \frac{24}{95}$ and $\frac{31}{95}$ respectively after the Cameroons ceased to be a part of Nigeria in 1961). The Raisman Commission left external borrowing in the hand of

\footnotetext{
${ }^{39}$ Nnamdi Azikiwe, Selected Speeches of Nnamdi Azikiwe (London, 1961), p. 188.

${ }^{40}$ Awa, Federal Government, p. 205.
} 
the Federal Government. In addition, the Commission recommended that the Federal Government take the responsibility of exploring and exploiting the continental shelf of Nigeria. The proceeds of the mineral wealth be shared as follows: 50 percent to go to the region which possessed the mineral wealth, 20 percent to be given to the Federal Government, 30 percent be distributed to the distributable pool. 41

\section{DEFENSE AND INTERNAL SECURITY}

Nigerian defense and police forces owed their beginnings and growth to Britain. The Royal Niger Company and the Niger Coast Protectorate were the first to organize defense forces. The forces comprised five British and two African officers and four hundred infantry, largely drawn from the Gold Coast. The duty of these forces was to protect the companies against French powers in the territories. They also protected the unfriendly coastal tribes like the Brassmen, who often destroyed or broke into the companies' stores.

In 1900, Lord Lugard organized the West African Frontier Force, still for the purpose of holding off French. 42 In 1901, the Royal Niger Company and the Niger Coast Protectorate forces were joined together to form the Southern Nigeria Regiment of the West African Frontier Force. The Southern Nigeria Regiment was all Nigerians with British commanding officers at the head. After the

$$
\begin{aligned}
& { }^{41} \text { Ibid., p. } 208 . \\
& { }^{42} \text { Kenneth Kirkwood, Britain and Africa (Great Britain, 1965), p. } 26 .
\end{aligned}
$$


Amalgamation of 1914, these forces became the Nigeria Regiment. ${ }^{43}$ When the first World War broke out, the Nigeria Regiment defended the country against the German Cameroons. It also fought on the British side in the second World Wor against Germany. Nigeria defense force influence was mostly felt in some parts of the Middle and Far East.

Since then, the defense force rested wholly on the British Government. In 1957, it was agreed at the London Constitutional Conference that the control exercised by the United Kingdom should cease after April 1958. As from 1959, the Defense Committee consisted of the Governor-General as the chairman, the deputy governor-general, the Prime Minister of the Federation, two other federal ministers, the regional premiers or their representatives, and the officers commanding the military forces. As from October 1, 1960, the chairman of the Defense Committee was the Prime Minister, Sir Balewa. 44

With the experience of defense thus gained from British Colonial rule, the Nigerian leaders were able to reflect this experience before and after independence. During the 1959 election campaign, the leader of the N.C.N.C., Dr. Nnandi Azikiwe, in his statements on foreign policy, rejected military alliance with any geo-political group. But one month after independence, Nigerian government signed a defense pact with Britain and gronted her overflying rights for the purpose of testing aeroplanes in tropical conditions. The reasons for the

$$
\begin{aligned}
& 43 \text { Awa, Federal Government, p. } 265 . \\
& { }^{44} \text { Ibid., p. } 265 .
\end{aligned}
$$


action were, first, Britain was and continues to be, the mother country to Nigeria. Second, it was a mutual advantage to Britain and Nigerio to cooperate in defense field. As a reciprocal favor, Nigeria was offered the sale of certain types of weapons and training facilities in the United Kingdom for her forces. 45 However, in 1961, the mutual agreement policy was abolished because the policy was severely criticized by the public.

In 1960, when the British Government requested that Nigeria should accept mutual defense agreement with Britain as a condition for granting independence, Chief Awolowo opposed the idea bitterly. He was aware of the fact that Britain-Nigeria mutual agreement meant that Nigeria would depend on the British military power.

The police force was first organized during the first World Wor for the purpose of maintaining low and order. As in the defense force, the police force was made up of Nigerians with British officers commanding. Between 1940 and 1942, there was a sudden rise in prices of food stuffs. The rise in price was one of the effects brought about by the second World War. There was no raise in wages or salaries of workers proportionate to the rise in prices. The effect of the inflation was felt heavily by working class. The result was that the labor union leaders called out workers on strike. The action of the workers was interpreted by the government as a challenge. The Government therefore formulated Nigeria Defense Regulation, which made strike illegal in 1942.

45 Mackintosh, Nigerian Government, p. 271. 
As the condition of the strikers and the general public worsened, security officers were enrolled to maintain peace, law and order. Those who were first enrolled were the retired expatriates and their wives and some able Africans. From that date, the institution of police force became a permanent establishment. In the North, members of the Federal Force were mainly recruited from the nonMoslem tribes since police work was not a popular employment for the HausaFulani educated group. ${ }^{46}$ In the South, interested educated members enrolled.

As the Nigerian leaders understood more and more about internal security, they were much more concerned about where the concentration of power should be. Abubakar Balewa, Ahmadu Bello and Chief Obamfemi Awolowo favored regional control. The reason was that they wanted law and order to be effectively maintained. Nnamdi Azikiwe preferred federal control. He was afraid that tribal influence would affect the security officers in carrying out their normal duties, especially during political crises. The latter opinion was a sound one because the three major policial parties were, and continue to be, tribalistic and sectional oriented. The decision to place the police force under the command or control of the Federal Government was taken during the 1958 London Constitutional Conference. This decision was influenced by the British Government. Internal security, in Nigeria, is still the responsibility of the Federal Government today. 46 John Smith, Colonial Cadet in Nigeria (Durham, 1968), p. 74. 


\section{$X$. THREE ORGANS OF GOVERNMENT}

Functional and organizational influence and experience in legislative, executive and judiciary branches of the government were correctly instilled into Nigerian leaders during the British Colonial rule.

Nigeria Legislature is made up of the House of Representatives and the Senate. Between 1952 and 1954, the House of Representatives consisted of 136 elected members and six members appointed by the Governor. After the resumed Constitutional Conference of 1958, the strength of the lower house was 312.47 Representation was as follows: 174 seats were allocated to the Northern region, 62 seats to the Western region, 73 seats to the Eastern region, and 3 seats to the Federal territory, Lagos. Each region sent twelve representatives to the Senate. Specific powers were given to the Nigerian Parliament. It was given the power to make laws on all matters, in times of peace or in times of war. It had the power to make laws for any region, which, in the opinion of the Parliament, the executive power of that region makes it impossible for the Federal executive government to exercise its power. It made laws in all matters for the purpose of implementing any treaty, convention or agreement between the Federal Government and any other country.

The Federal executive was the Governor, and the members were the ministers. The Governor exercised such powers assigned to him. For example, a Federal bill could not become law until he gave his assent. Bills passed by the ${ }^{47}$ Burns, History of Nigeria, p. 258. 
regional legislatures were sent to the Governor for approval. He had the power to appoint members to the House of Representatives. In 1954, the Governor became Governor-General and Commander-in-Chief of the armed forces. In other words, he was responsible for defense and external matters. The Council of Ministers was responsible for making of foreign policies.

In the judiciary branch, the Federal Supreme Court was the head. High courts were established in regions. Below it, were the magistrate courts and Native Courts. Formally, the Supreme Court consisted of Chief Justice of the Federation and at least two Federal Justices. By 1958, the Federal Supreme Court was enlarged by addition of Chief Justice of each region. The specific duty of the Supreme Court was to settle disputes between the Federal Government and the regional governments, or between two regional governments. It answered questions relating to the interpretation of the Constitution. It acted in an advisory capacity on matters arising from each region. It heard appeals from Regional High Courts. Since the early Colonial history, the Supreme Court and the provincial courts administered English laws as modified by the Nigeria local ordinances and native customs. 48

Chief Obamfemi Awolowo was effectively educated in the three branches of the government. In The People's Republic, he spoke vehemently in favor of separation of powers. 49 He believed that to concentrate all the three functions

${ }^{48}$ Geary, British Rule, p. 268. ${ }^{49}$ Awolowo, People's Republic, p. 291. 
in the hand of one person, in any country, was bound to lead to a state of tyranny. 50 Awolowo feared that concentration of the three powers into one man's hand might compel the man to wield the powers in favor of some people. According to Chief Awolowo, he would do so specifically to his family, relatives, or even to his friends, to the detriment of others. The executive, for example, should not perform the functions of the legislature even though the same persons may be members of both. The legislature, for example, may not interfere with the judicature or the executive nor could it exercise any controlling influence.

In the North, Bello created the following offices for these ministers when he took over the local government: Premier -- Sardauna (Bello); Education -Makaman Bida; Natural Resources -- P. S. Achimugu; Trade and Industry -- A. Turakin Zaria; Works -- Isa Kaita; Development and Survey -- Shettima Kashim; Local Government -- Bello; North Cameroons Affairs -- Abba Habib; Health -Yahaya llorin. He set up a privy council with the duty of advising the premier on the exercise of the prerogative of mercy. This was formerly in the Governor's discretion with the advice of the executive council. Bello was well-educated on the three organs of the government. He, with the advice of the ministers, drew up a budget estimate or expenditure estimate amounting to over twelve million pounds for the services of Northern Nigeria.

Addressing the Senate on the eleventh of January 1960, Dr. Azikiwe, who became the President of the Senate, told the members that bicameral

$50_{\text {lbid., p. } 108 .}$ 
legislatures were popular both in the Dominions of the Commonwealth and in many sovereign nations. That the upper house was created to give much thought to bills which might not have been given careful consideration during the initial stages. He pointed out that Senators were expected to study very carefully and objectively every bill given to the House. He emphasized that the upper house had the power to delay a bill which in the opinion of the majority such a bill should be delayed. He also informed them that the House had no power to obstruct the passage of legislation. 51 Winding up the powers of the upper house, the President made it abundantly clear that the Senate had no power to initiate or delay money bills and that other bills could be delayed for a period not exceeding six months.

\section{EDUCATION}

Christian education first came into Nigeria through European missionaries, largely from Great Britain. The Wesleyan missionaries arrived in Abeokuta, in the Western territory, in 1846. In the same year, Presbyterian mission began work in Calabar, in the Eastern territory. These missionaries did lay a solid foundation of experience and influence in educational advancement. Many primary and secondary -- even colleges -- today still bear British names. 52

The school-leaving Certificate Examination Standards including the curriculum of all Nigerian secondary schools had been to a certain extent modeled

${ }^{51}$ Azikiwe, Speeches, p. 143.

${ }^{52}$ Mary Slesson School at Calabar, and MacGregor College at Afikpo. 
after those of the English grammar schools. ${ }^{53}$ Some Nigerian textbooks, such as reading books and arithmetic workbooks, still bear British backgrounds. For example, Nigerian children in primary schools still read about the Westminster Abbey.

In 1942, the Secretary of State for the Colonies appointed a commission to study facts on West African education with a view to making recommendations for the building of a university in British West Africa. ${ }^{54}$ The report of the commission was presented to Parliament in June 1945. This recommendation or report became the basis for the development of higher education in Nigeria. In 1930, the Colonial government had already opened a medical school in Lagos and Yaba Higher College in 1934. By 1945, sixty-nine owards were given to Nigerians to study in the United Kingdom. The total number of Nigerians who studied in the United Kingdom from the awards was as follows: fifty-seven studied law; fifty-one studied medicine, and fifteen learned engineering.

In 1948, the University College was built in Ibadan, in the Western region. Although the University College was built through the instrumentality of Chief Awolowo and other Western Nigeria educated elites, it served as a living example of British influence in the sense that degrees were originally awarded by University of London. 55 Today, many more universities have been built, such as

${ }^{53}$ Coleman, Nigeria, p. 120.

54 The first West African university was Fourabay College, built in Sierra Leone.

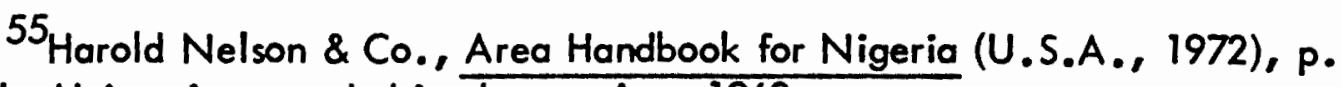
184. The University awarded its degree since 1962. 
the Ahmadu Bello University in Zoria, 1962; the University of Lagos, 1962; the University of Ife, 1961; and the University of Nigeria-Nsukka, 1960. The University College lbadan, mainly staffed with British professors, did train the characters of the future Nigerian leaders. Moreover, this literary education had placed special emphasis on the English language which is especial prestige to the educated class as well as a means of socialization in the eyes of most Nigerians. Education in the political process obviously had a direct participation in the quasi-parliamentary institutions introduced by Britain and modeled from British pattern. The wide variety of political experiences which the party leaders offered were all borrowed experiences of the Western civilizations, mostly from Britain. Like social change, political change is decidedly controlled by education. 


\section{CHAPTER VI}

\section{PRACTICAL EXPERIENCE IN SELF-GOVERNMENT 1956-60}

\section{MOTION FOR SELF-GOVERNMENT}

Members to the House of Representatives and the regional House of Assemblies were elected in 1951. In March 1953, a motion for the granting of internal self-government, effective in December 1956, was made in the House of Representatives, in Lagos, by Chief Anthony Enaboro.' The motion was amended by Sir Ahmadu Bello to read, " . . as soon as practicable. ${ }^{2}$ This amendment brought heated debate to the extent that members of the N.C.N.C. and A.G. walked out of the House. The N.P.C. leaders who opposed it were openly abused by the Lagos mass and were badly criticized and ridiculed as "imperialistic stooges." On their return to their home region, they vowed never agoin would they be subjected to the Southern indignities. To show their determination, they issued a statement of secession of the region from Nigeria.

Still determined to push for internal self-government in 1956, the A.G., under the leadership of Chief Samuel Akintola, led a delegation to the Northern leaders. Chief Akintola summoned a meeting which lasted for four days in Kano.

'Chief Enaboro was the leader of opposition party in the Northern House of Assembly, a strong A.G. member.

${ }^{2}$ Coleman, Nigeria, p. 399. 
All the Northern political leaders and other Northerners attended the meeting. Other non-Northerners, such as the lbos, the Yorubas, and the lbibios who were members of the N.C.N.C. or the A.G., but who lived in the North, were also present. The delegates insisted that the Northern political leaders should accept the Southern political leaders' view of internal self-government in 1956. Differences of opinions, mixed with emotional feelings on both sides, resulted in "Kano Riot" with 277 casualties, including thirty-six deaths. 3

On July 1953, Oliver Lyttleton, the Colonial Secretary, convened a Constitutional Conference in London to revise the 1951 Constitution by providing for greater regional autonomy and removing of powers of intervention by the centre. In the conference, the N.C.N.C. and the A.G. leaders repeatedly demanded self-government for Nigeria in 1956, while the N.P.C. delegation continued to oppose it. In the circumstances, the Colonial Secretary compromised by stating that the British Government would be willing to grant full internal self-government to any region that wanted it in 1956.

Further conference was held in Lagos in January 1954. The results of the two conferences were visible on October 1, 1954: a Council of Ministers was created. It consisted of Governor-General who was the President of the Council, three ex officio members -- the Chief Secretary, the Attorney General, and the Financial Secretary of the Federation-- and ten ministers. Three ministers were chosen from each region. But one was appointed to represent Cameroons. Each

${ }^{3}$ Fiffeen Northerners and twenty-one Southerners were killed. 
region had executive council comprising the Governor, who was the president, a premier of the region, who was a Nigerian but appointed by the Governor, and a number of regional ministers. All were Nigerians, but appointed by the Governor on the recommendation of the premiers. The Southern Cameroons had commissioners, three ex officio and four unofficial members appointed by GovernorGeneral. The members appointed were from the Southern House of Assembly in Cameroons. In other words, the Nigerian ministers were now given ministerial responsibility for individual government departments.

The London Conference convened in 1957 was concerned with the granting of formal self-government. The conference made possible two important developments: first, after its adjournment, a formal attainment of internal selfgovernment by the Eastern and the Western governments on August 8 was possible. Second, National Government was formed, comprising members from the three major parties.

\section{FORMATION OF NATIONAL GOVERNMENT ${ }^{4}$}

Alhaji Abubakar Tafawa Balewa -- Prime Minister and Minister of Finance (N.P.C.)

Mallam Buka Dyscharima -- Minister of State (N.P.C.)

Alhaji Muhammadu Ribadu -- Minister of Logos Affairs, Mines and Power Alhaji Inuwa Wada -- Minister of Works and Surveys

${ }^{4}$ Crowder, Short History, p. 331. 
Chief Kola Balogun -- Minister of Research and Information (N.C.N.C.)

Mr. J. M. Johnson -- Minister of Internal Affairs

Dr. K. O. Mbadive -- Minister of Commerce and Industry

Mr. R. A. Nioku -- Minister of Transport

Mr. Aja Nwachuku -- Minister of Education

Chief Festus Okotie Ebo -- Minister of Labor and Welfare

Chief Samuel L. Akintola -- Minister of Communication and Aviation (A.G.)

Mr. Ayo Rosiii -- Minister of Health

Mr. Victor Mulc ete -- Minister of State (K.N.C. (Kamerun National Congress))

In forming the above National Government, Sir Abubakar Bolewa was guided by the experience of 1954 Federal Government.

\section{1954 FEDERAL GOVERNMENT}

Northern Region

Mallam Abubakar Tafawa Bolewa -- Minister of Transport (N.P.C.)

Alhaji Inuwa Wada -- Federal Minister (N.P.C.)

Mallam Muhannaden Ribadu -- Minister of Land, Mines, and Power (N.P.C.) 


\section{Westem Region}

Alhaji Adegoke Adelaba -- Minister of Natural Resources and Social Service (N.C.N.C.)

Chief Kola Balogun -- Minister of Research and Information (N.C.N.C.)

Chief Festus Okofie Eboh -- Minister of Lobor and Welfare (N.C.N.C.)

\section{Eastern Region}

Mr. Raymond Nioku -- Minister of Trade and Industry (N.C.N.C.)

Dr. K. O. Mbadive -- Minister of Cojmmunications and Aviation (N.C.N.C.)

Mr. M. T. Mbu -- Federal Minister (N.C.N.C.)

Southern Cameroons

Mr. Victor Mukete -- Federal Minister (N.C.N.C.)

Ex Officio Members

Governor-General -- President

Chief Secretary

Financial Secretary

Attorney General

\section{WESTERN GOVERNMENT}

In the Western region, Chief Awolowo reflected his experiences in many different administrative fields: he created some few ministries, for example, 
Ministry of Education was headed by Mr. S. O. Awokeja, Mr. E. A. Babalola was in charge of Ministry of Works. His Highness Aholu Liwa II managed Ministry of Development.

In studying the estimate of his government, he was guided by three principles: (a) social needs; (b) policy of Nigerianization; (c) expenditure on welfare. He believed that health and education of the people should be increased at the expense of any expenditure that does not measure to the same need. 5 He provided eighty thousand pounds in the estimate for the award of two hundred post-secondary scholarships, tenable in British and American universities, as well as in the University College Ibadan. Furthermore, he provided twenty-five thousand pounds for recreational facilities.

His development plans for 1955-60 and for 1960-65 covered such fields as education, recreation, health and agriculture. By 1958, the Western Nigeria Development Corporation had six plantations of its own, covering 20,517 acres. Cooperative societies and Local Government Authorities had eleven plantations, covering 8,463 acres. Rubber, cocoa, oil palm, citrus, cashew, and coffee were planted on these acres of land.

When Awolowo met with financial problems in education and health, he imposed a levy of ten shillings on all adult male taxpayers. During his eight years ${ }^{6}$

${ }^{5}$ Awolowo, Autobiography, p. 263.

${ }^{6}$ Head of local government in 1952-53, Premier in 1954-59. 
in office, he paid special attention to the formation of all major policies as well as execution of all important programs.

\section{EASTERN GOVERNMENT}

Eastern government, like the Western Government, was formed and run by the Eastern Premier, Dr. Nnamdi Azikiwe, in the same broad pattern. For example, he created Ministry of Town Planning, Education, Transportation, Works, and Agriculture. These two regions were often in keen competition with one another except that the Western regional government did maintain a clear lead in planning and carrying out most activities becouse of its many more financial resources. For instance, the government of the Western region introduced free primary education in 1955, while universal primary education was started in the Eastern region in 1957.7

\section{MINORITY FEARS}

Minority fears as regional problem became clearly a part of experience to Nigerian premiers on how the component parts of the country should be kept united. 8 As independence drew nearer, the leaders of the minority groups -Chief Edet Okun Eyo, Mr. Joseph Sarwuan Tarka, Chief Nyong Esien, and Chief Anthony Anahoro -- became much concerned as to what the fate of the minorities

\footnotetext{
${ }^{7}$ School fees were paid by pupils in primary $3-5$.

${ }^{8}$ Coleman, Nigerio, p. 384.
} 
would be. They feared that the dominant groups will in one way or another misuse political powers. For this reason, they demanded their own separate states 9 where they will maintain their own identity. This demand was right becouse essentially, self-government meant that power would pass to Nigerians who would be able to command mojority in the existing political subdivisions of the country, the regions. The three regional parties, in effect, were controlled by leaders of the numerical dominant cultural groups: the N.P.C. by the Hausa-Fulani, the N.C.N.C. by the lbo, and the A.G. by the Yoruba. Thus, self-government to some of the minority leaders was to be permanently controlled by Hausa, Yoruba, or lbo domination. The only safeguard for the minority was the demand for separate states as the only measure whereby they could maintain their status in independent Nigeria.

The matter of creating more regions for the minority groups was discussed during the London Conference. The only single leader who consented to the creation of more regions for the minorities was Chief Awolowo. Dr. Nnamdi Azikiwe condemned the idea of more states for the East because he did not want the East to be dismembered as a sacrifice for administrative purpose or national unity. Sir Bello, on the other hand, stood firm for "one North, one people, no matter what religion, rank, or tribe."

However, in recognition of this problem, the Northern and the Eastern premiers in their respective home regions created provincial system of government ${ }^{9}$ North -- Middle Belt, East -- COR State, West -- Midwest State; Midwest State was created in 1963; Chief Denis Osadebay was the Premier. 
by establishing Provincial Assemblies. This device did not solve the fears.

TABLE I

PRINCIPAL ETHNIC GROUPS (CENSUS 1952)

\begin{tabular}{lrrcc}
\hline \multicolumn{1}{c}{ Area } & Number & North & East & West \\
\hline Hausa & $5,547,000$ & $99 \%$ & - & - \\
lbo & $5,482,000$ & $3 \%$ & $91 \%$ & $6 \%$ \\
Yoruba & $5,046,000$ & $10 \%$ & $1 \%$ & $89 \%$ \\
Fulani & $3,040,000$ & $99 \%$ & - & - \\
Kanuri & $1,301,000$ & $99 \%$ & - & - \\
Tiv $^{+}$ & 789,000 & $97 \%$ & $3 \%$ & - \\
lbibio $^{+}$ & 765,000 & $2 \%$ & $97 \%$ & $1 \%$ \\
Others (liaw, $_{\text {Efik, etc.) }}^{+}$ & $9,184,000$ & & & \\
Total & $31,154,000$ & & & \\
\hline
\end{tabular}

SOURCE: The Nigerian Geographical Journal, Vol. 2, p. 7.

$-=$ Less than $1 \%$

$t=$ Minorities

At the same time, the British Government sent Willink Commission to study the minority fears and make some recommendations. Surprisingly, the Commission advised against the creation of more regions, holding that the new $\mathrm{Ni}$ gerian national ism would eventually weaken the local tribal feelings. Specifically, the Commission recommended distribution of powers and functions to parties in power so as to aid them pay attention to the needs of the minorities.

The decision of the Commission was influenced by three reasons: in the first place, the British Government earlier opposed to the creation of new states. 


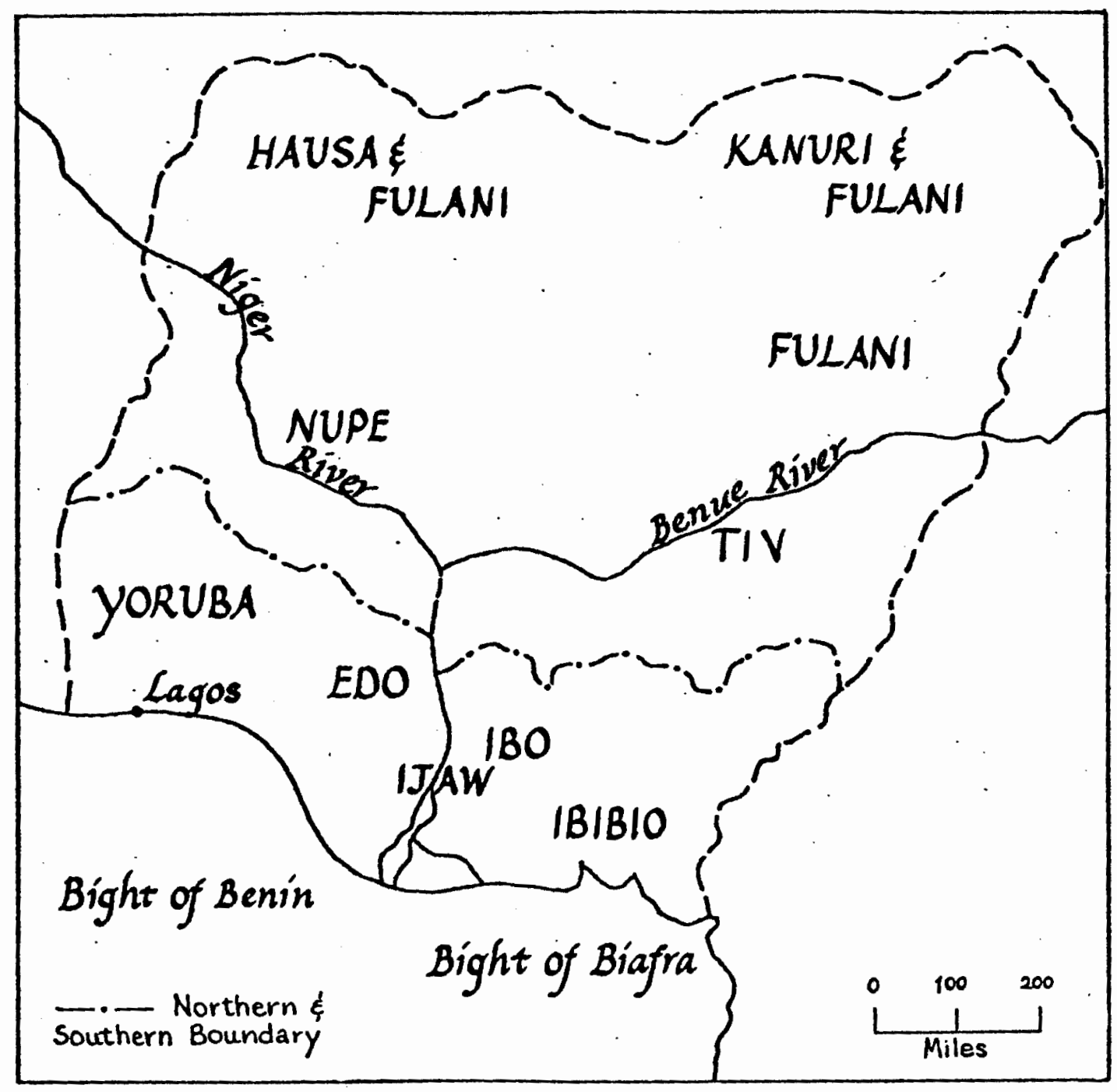

Figure 6. Nigerio -- Chief Tribes. 
The reason was that it would increose administrative problem. In the second place, the N.P.C. and the N.C.N.C., who controlled the Federal Government since 1954, strongly kicked against the creation of additional regions. Finally, the Commission based its conclusion on one assumption. It believed that Nigeria would continue to follow the system of liberal democracy and parliamentary government after independence. Thus, each of the major parties would be compelled to seek the favor of the minorities, in order to win seats in the Federal House of Representatives.

The Willink's recommendation was, in the author's opinion, misleading, in the sense that the Commission failed to clarify the specific power and function to be applied. Even though the minority problem remained unsettled, ${ }^{10}$ the approach taken by the British Government and the recommendations of the Commission did give the leaders experience on how to deal with such problems in independent Nigeria.

${ }^{10}$ Twelve states were finally created in 1966: six in the North and six in the South. 


\section{CHAPTER VII}

\section{CONCLUSION}

In a country like Nigeria, with about 250 distinctive tribes and 280 languages or dialects and with a wide variety of habits and customs, the British rule gradually pulled these diversed peoples together. The amalgamation of 1914 of the North and the South was a deliberate action toward unity of the country. The maintenance of law and order through the police force, the administrative unity of the Civil Service, the fiscal and economic integration, all served to link together the heterogeneous elements which made up the Nigerion society. The Nigerion leaders who created and took over the leadership of the Nationist movement, the fact of a common British or Western background, is almost as evident as the foct of a common Nigerian heritage.

The introduction of English as a linqua franca served three major purposes in the country which have an obvious bearing on the effort to secure national cultural identity. In the first place, English was and is the language of instruction in all Nigerion schools, colleges, and universities. In the second place, it had been the instrument and influence by which Nigerian leaders and other educated citizens communicate with the Western world. And finally, it served as official language in Nigeria. 
Britain's influence and experience were also felt in medical development, largely through missionaries. The missionaries started the first health centres in such places as Calabar and Benin. These health centres gradually developed into mission hospitals. The Methodist hospital at Ituk Mbang, St. Joseph hospital at Anua, and the Qua Iboe hospital at Etinan, all in the Eastern region, served as examples of medical institutions established during the Colonial period. The University Teaching hospital at Ibadan opened in 1957 and other Government hospitals were built through the influence of these mission hospitals. These hospitals were staffed with doctors trained in United Kingdom.

Another essential aspect of influence and experience was on the system of communication. The construction of railway started since 1896 by Frederick Lugard. The Western line was constructed at Ebute Metta on the mainland of Lagos. By 1900, it spread into the interior as far as to lbadan, and to Jebba on the Niger, by the end of 1909. The Eastern division of the railway began at Portharcourt and passed to the Enugu cool field and then to Benue at Makurdi. Before Britain left Nigeria, the railway system governed important areas. Today, the total mileage is about 2,680 .

It is therefore true to believe that Britain's Colonial rule made sufficient allowance for the growth in experience and influence of the Western educated elites, who took over the reins of government. On independence, Nigeria had six years of experience as a Federal State. The regions had already had some experiences in self-government. The political parties had been in existence for more than a decade. The leaders, under the British rule, were shown how to 
solve several problems which would confront them. They were shown how to deal with such problems as balance between the centre and the regions, minority problems, and fiscal allocations. They were well-informed or shown how to be broadly united. They were given enough chance to put forth numerous plans for national policy. They had ample opportunities to test their experiences in parliamentary set-up. The premier of Northern Government, Sir Bello; the premier of the Eastern region, Dr. Azikiwe; and the premier of the West, Chief Awolowo; even the Prime Minister, Sir Balewa; have all been put through the parliamentary framework which gave the experience on how the majority should govern and at the same time, how the minority ought to be protected with right. 


\section{A SELECTED BIBLIOGRAPHY}

Adedeji, Adebayo. Nigerian Administration and its Political Setting. London, 1968.

Ajoyi and Crowder. History of West Africa. Vol. II. New York, 1973.

Azikiwe, Nnamdi. My Odyssey -- An Autobiography of Zikiwe. New York, 1970. - Selected Speeches of Nnamdi Azikiwe. London, 1961.

Awa, Eme O. Federal Government in Nigeria. London, 1964.

Awolowo, Obamfemi. The People's Republic. Ibadan, Nigeria, 1968.

Awo, Obamfemi. The Autobiography of Chief Obamfemi Awolowo. London, 1960.

Bello, Alhaii Ahmadu. My Life. London, 1962.

Burns, Sir Allan. History of Nigeria. London, 1969.

Coleman, James S. Nigeria - Background to Nationalism. U.S.A., 1960.

Crowder, Michael. A Short Mistory of Nigeria. New York, 1966.

Crocker, W. R. Nigeria - Critique of British Colonial Administration. London, 1936.

Crowder, Michoel. West Africa Under Colonial Rule. Great Britain, 1968.

Dudley, B. S. Parties and Politics in Northern Nigeria. Great Britain, 1968.

Geary, Williams. Nigeria Under British Rule. London, 1965.

Hazzledine, George Douglas. The White Man in Nigeria. New York, 1969.

Hogben, S. J., and Grene, Kirk. Emirates of Northern Nigeria. London, 1966. 
Ikime, Obaro. Merchant Prince of the Niger Delta. New York, 1968.

Johnson, H. A. S. The Fulani Empire of Sokoto. London, 1967.

Kirkwood, Kenneth. Britain and Africa. Great Britain, 1965.

Kirk, Grene A. H. M. The Principles of Native Administration in Nigeria. London, 1965.

Lugard, Lord Frederick. The Dual Mandate of British Tropical Africa. London, 1965.

Mackintosh, John P. Nigerian Government and Politics. Great Britain, 1966.

Meek, C. K. Law and Authority in a Nigerian Tribe (A Study in Indirect Rule).

Niven, Rex. Nigeria. New York, 1967.

Nicolson, 1. F. The Administration of Nigeria 1900-1960. London, 1969.

Nelson, Harold D., and Co. Area Handbook for Nigeria. U.S.A., 1972.

Perham, Margery. Native Administration in Nigeria. London, 1962.

Phillips, Claude S. The Development of Nigeria Foreign Policy. U.S.A., 1964.

Schwarz, Frederick. Nigeria -- The Tribes, the Nation or Race -- the Politics of Independence. England, 1965.

Schwarz, Walter. Nigeria. London, 1968.

Sklar, Richard L. Nigerian Political Parties. U.S.A., 1963.

Smith, John. Colonial Cadet in Nigerio. Durham, 1968.

Smith, Sir Bryan Sharwood. Recollections of British Administration in the Cameroons and Northern Nigeria 1921-1957. U.S.A., 1969.

- But Always As a Friend -- Northern Nigeria and the Cameroons 1921-1957. U.S.A., 1969.

Temple, C. L. Native Races and Their Rulers. London, 1968.

Talbot, P. Anoury. Life in Southern Nigeria. New York, 1967. 
Whitaker, C. S. The Politics of Tradition, Continuity and Change in Northern Nigeria 1946-1966. U.S.A., 1970.

The Nigerian Geographical Journal. Vol. 2. 